\title{
Hydrogeology and Hydrologic Landscape Regions of Nevada
}

Scientific Investigations Report 2004-5131

Prepared in cooperation with the NEVADA DEPARTMENT OF CONSERVATION AND NATURAL RESOURCES, NEVADA DIVISION OF ENVIRONMENTAL PROTECTION

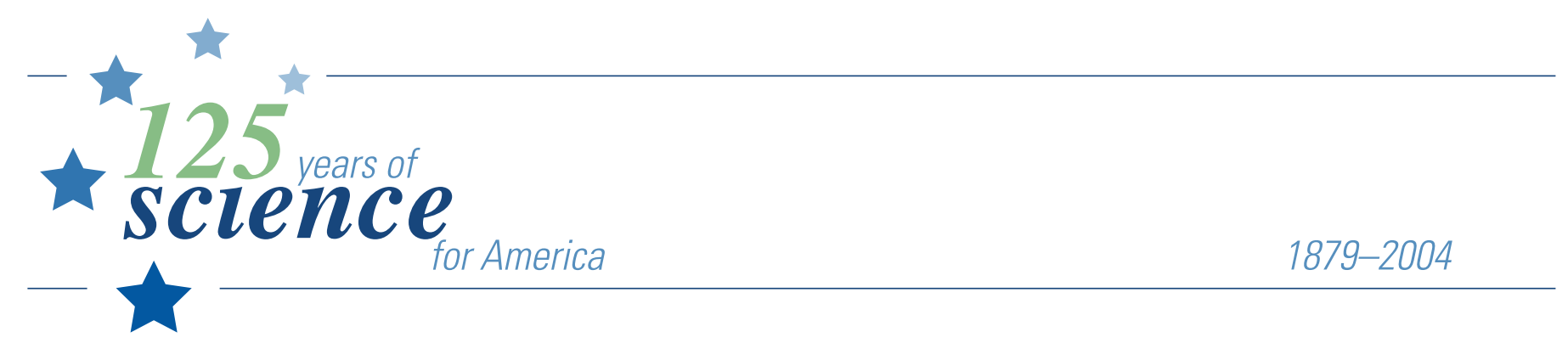

U.S. Department of the Interior

U.S. Geological Survey 
(Back of Cover) 


\section{Hydrogeology and Hydrologic Landscape Regions of Nevada}

By Douglas K. Maurer, Thomas J. Lopes, Rose L. Medina, and J. LaRue Smith

U.S. GEOLOGICAL SURVEY

Scientific Investigations Report 2004-5131

Prepared in cooperation with the NEVADA DEPARTMENT OF CONSERVATION AND NATURAL RESOURCES, NEVADA DIVISION OF ENVIRONMENTAL PROTECTION 


\title{
U.S. DEPARTMENT OF THE INTERIOR GALE A. NORTON, Secretary
}

\author{
U.S. GEOLOGICAL SURVEY
}

CHARLES G. GROAT, Director

Any use of trade, product, or firm names in this publication is for descriptive purposes only and does not imply endorsement by the U.S. Government

For additional information contact:

District Chief

U.S. Geological Survey 333 West Nye Lane, Room 203

Carson City, NV 89706-0866

email: GS-W-NVpublic-info @ usgs.gov

http://nevada.usgs.gov
Copies of this report can be purchased from:

U.S. Geological Survey Information Services

Building 810

Box 25286, Federal Center

Denver, CO 80225-0286 


\section{CONTENTS}

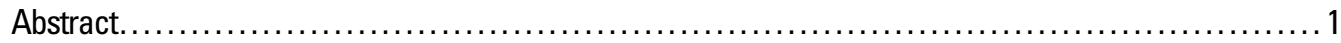

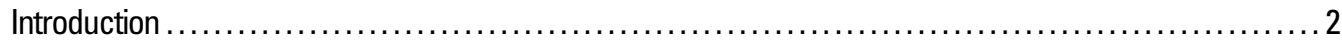

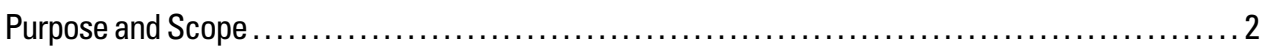

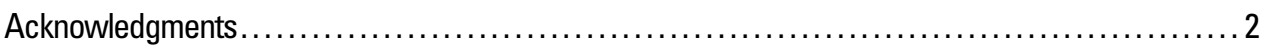

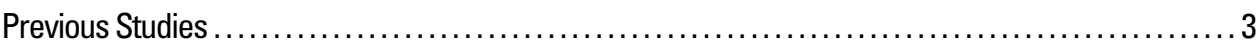

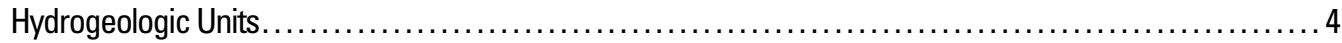

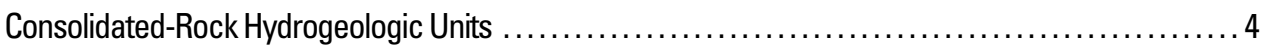

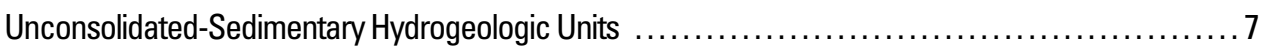

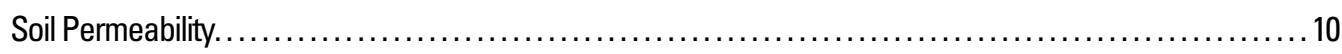

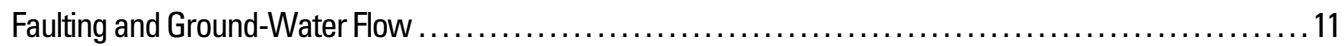

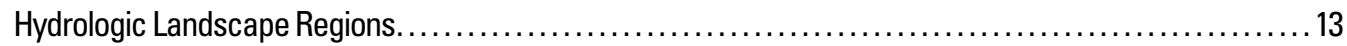

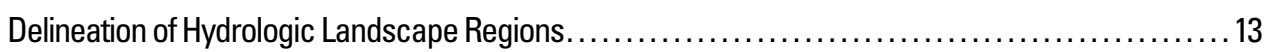

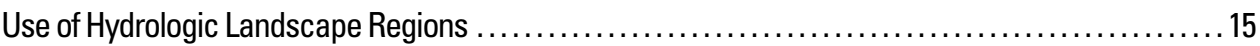

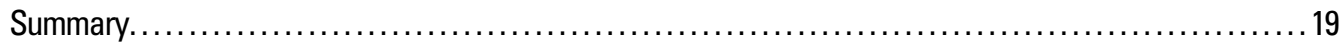

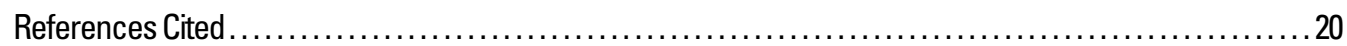

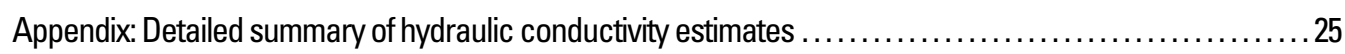

Supplemental Geospatial Digital Data:

Hydrologic landscape regions of Nevada, byJ. LaRue Smith <http://water.usgs.gov/lookup/getspatial?nv_hlrnv_g> Hydrogeology of Nevada byRose L. Medina <http://water.usgs.gov/lookup/getspatial?nv_hydgeolnv_p>

\section{FIGURES}

1. Diagram showing ground-water flow characteristics for different types of hydrographic areas

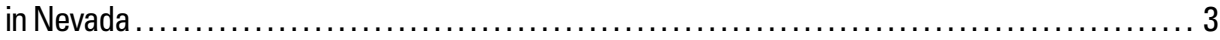

2. Graph showing range in horizontal hydraulic conductivity for hydrogeologic units. .......... 7

3. Diagram showing typical ground-water flow patterns perpendicular to the long axis of valleys in Nevada for mountain blocks with different permeability and annual precipitation .............9

4. Diagram showing potential effects of faults on ground-water flow for different types of aquifer

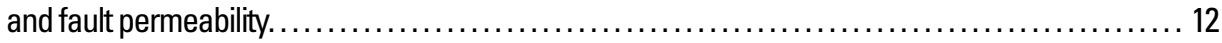

5. Graph showing ranges in mean annual precipitation, soil permeability, slope, and aspect for hydrologic landscape regions with low and high horizontal hydraulic conductivity $\ldots \ldots \ldots \ldots \ldots 15$

6. Map showing hydrologic landscape regions $9,10,14$, and 15 in the most urbanized areas of Nevada.

\section{PLATES}

1. Map showing distribution of consolidated rocks and unconsolidated sediments, historic to Quaternary-age faults, and springs in Nevada

2. Map showing distribution of hydrogeologic units in Nevada

3. Map showing areas of similar soil permeability and hardpan in Nevada

4. Map showing hydrologic landscape regions of Nevada 


\section{TABLES}

1. Correlation of hydrogeologic units with geologic-map units of Stewart and Carlson (1978a) ....... 5

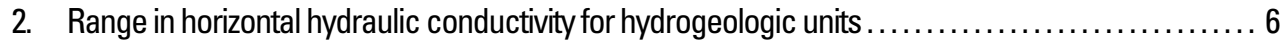

3. Range in soil permeability for descriptive categories of unconsolidated sediments and

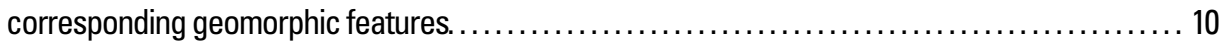

4. Characteristics, distribution, area, and population of hydrologic landscape regions ............ 16

5. Example of a sampling strategy using hydrologic landscape regions..................... 19

\section{CONVERSION FACTORS}

\begin{tabular}{rll}
\hline Multiply & By & To obtain \\
\hline foot $(\mathrm{ft})$ & 0.3048 & meter \\
foot per day (ft/d) & 0.3048 & meter per day \\
gallon per minute $(\mathrm{gal} / \mathrm{min})$ & 0.06309 & liter per second \\
inch (in.) & 25.4 & millimeter \\
mile (mi) & 1.609 & kilometer \\
square mile $\left(\mathrm{mi}^{2}\right)$ & 2.590 & square kilometer \\
\hline
\end{tabular}




\title{
Hydrogeology and Hydrologic Landscape Regions of Nevada
}

\author{
By Douglas K. Maurer, Thomas J. Lopes, Rose L. Medina, and J. LaRue Smith
}

\section{Abstract}

In 1999, the U.S. Environmental Protection Agency initiated a rule to protect ground water in areas other than sourcewater protection areas. These other sensitive ground water areas (OSGWAs) are aquifers that are not currently but could eventually be used as a source of drinking water. The OSGWA program specifically addresses existing wells that are used for underground injection of motor vehicle waste. If the injection well is in a ground-water protection area or an OSGWA, well owners must either close the well or apply for a permit. The Nevada Division of Environmental Protection will evaluate site-specific information and determine if the aquifer associated with a permit application is susceptible to contamination. A basic part of evaluating OSGWAs is characterizing the hydrogeology of aquifer systems including the lithology, hydrologic properties, soil permeability, and faulting, which partly control the susceptibility of ground water to contamination. Detailed studies that evaluate ground-water susceptibility are not practical in a largely unpopulated State like Nevada. However, existing and new information could be extrapolated to other areas of the State if there is an objective framework to transfer the information. The concept of hydrologic landscape regions, which identify areas with similar hydrologic characteristics, provides this framework. This report describes the hydrogeology and hydrologic landscape regions of Nevada.

Consolidated rocks that form mountain ranges and unconsolidated sediments that fill the basins between the ranges are grouped into hydrogeologic units having similar lithology and assumed to have similar hydrologic properties. Consolidated rocks and unconsolidated sediments are the two major hydrogeologic units and comprise 51 and 49 percent of the State, respectively. Consolidated rocks are subdivided into 8 hydrogeologic units. In approximate order of decreasing horizontal hydraulic conductivity, consolidated-rock hydrogeologic units consist of: (1) carbonate rocks, Quaternary to Tertiary age; (2) basaltic, (3) rhyolitic, and (4) andesitic volcanic flows; (5) volcanic breccias, tuffs, and volcanic rocks older than Tertiary age; (6) intrusive and metamorphic rocks; (7) consolidated and semi-consolidated tuffaceous rocks and sediments; and (8) clastic rocks consisting of sandstone and siltstone. Unconsolidated sediments are subdivided into four hydrogeologic units on the basis of flow regime, topographic slope, and mapped stream channels. The four units are (1) alluvial slopes, (2) valley floors, (3) fluvial deposits, and (4) playas.
Soil permeability was grouped into five descriptive categories ranging from very high to very low, which generally correspond to mapped geomorphic features such as playas and alluvial slopes. In general, soil permeability is low to moderate in northern, northeastern, and eastern Nevada and high to very high in western, southwestern, and southern Nevada. Within a particular basin, soil permeability decreases downslope from the bedrock contact. The type of parent rock, climate, and streamflow velocities are factors that likely cause these spatial patterns.

Faults in unconsolidated sediments usually are barriers to ground-water flow. In consolidated rocks, permeability and ground-water flow is reduced in directions normal to the fault zone and increased in directions parallel to the fault zone. With time, mineral precipitation may seal fractures in consolidated rocks, reducing the permeability. However, continued movement along the fault may form new fractures, resulting in a fault alternating from a zone of preferred flow to a flow barrier during geologic time. The effect of faults on ground-water flow at a particular location is difficult to determine without a sitespecific investigation.

Hydrologic landscape regions were delineated by overlaying a grid of 100-foot (30-meter) cells over the State, estimating the value of five variables for each cell, and conducting cluster analysis to assign each cell to a region such that each region is fairly homogeneous and distinct from other regions. The five variables include mean annual precipitation, soil permeability, slope, aspect, and hydrogeologic unit. The number of clusters was increased until each region had only one category of hydrogeologic unit, which resulted in 16 regions. Most of Nevada has moderate ( 8 to 16 inches) precipitation ( 58 percent), low (less than 5 feet per day) soil permeability (50.1 percent), moderate ( 3 to 25 percent) slope (58.1 percent), non-northerly aspect (88.7 percent), and hydrogeologic units with high (greater than 40 feet per day) horizontal hydraulic conductivity (59.8 percent).

Regions with moderate to high precipitation (equal to or greater than 8 inches per year), moderate to high soil permeability (greater than 5 feet per day), low to moderate slope (equal to or less than 25 percent), and high hydraulic conductivity could have greater recharge rates and be more susceptible to contamination than other regions. These characteristics describe hydrologic landscape regions 9, 14 and 15, which comprises 27.1 percent of Nevada. These hydrologic landscape regions represent valley floors and alluvial slopes of most basins in eastern and central Nevada. In the most populated areas of Nevada, hydro- 
logic landscape regions 9, 10, 14 and 15 comprise a large portion of Las Vegas, Reno, Carson City, Minden, Gardnerville, and Spanish Springs. These areas could be most vulnerable due to their hydrologic characteristics and contaminants associated with urban land-use practices.

\section{Introduction}

Protecting sources of drinking water from anthropogenic contamination is a priority for State and Federal Agencies. Programs to protect underground sources of drinking water, such as well-head and source-water protection programs, have been in place since the 1980s. The goal of these programs is to protect the quality of aquifers that are currently being used for public water supply. However, source-water protection areas comprise a small percentage of the aquifers in Nevada. It also is important to protect the quality of aquifers that are not currently but could eventually be used as a source of drinking water. In 1999, a new rule was initiated to protect ground water in areas other than source-water protection areas (U.S. Environmental Protection Agency, 2000). These other sensitive ground water areas (OSGWAs) could eventually be used as a source of drinking water. The rule gave regulatory agencies the option to designate specific sites, areas, or the entire state as an OSGWA. The Nevada Division of Environmental Protection (NDEP) elected to designate specific sites because of the unique geological condition that exists in the state.

The OSGWA program specifically addresses existing wells that are used for underground injection of motor vehicle waste; new injection wells are banned. If the injection well is in a ground-water protection area or an OSGWA, well owners must either close the well or apply for a permit. A permit is granted only if the injectate fluids meet drinking-water standards. Nevada is a large, rural, and hydrologically complex state. Except for populated areas, scant data makes it difficult to determine which aquifers could be vulnerable to contamination. Rather than designate all or specific areas of Nevada as an OSGWA, NDEP will evaluate site-specific information associated with a permit application to determine if the aquifer at that site is susceptible (Nevada Division of Environmental Protection, 2003). A basic part of evaluating OSGWAs is characterizing the lithology, hydrologic properties, soil permeability, and faulting of hydrogeologic units, which partly control the susceptibility of ground water to contamination.

Susceptibility and vulnerability are similar terms that have been used differently by different authors. This report uses the definition of Tesoriero and Voss (1997) who defined aquifer susceptibility as the "relative ease with which a contaminant applied on or near a land surface can migrate to the aquifer", and vulnerability as the "relative ease with which a contaminant applied at or near the land surface can migrate to an aquifer of interest, for a given set of land-use practices." The distinction is that susceptibility, also called sensitivity, considers only natural factors that affect how easily water recharges and moves through an aquifer (Focazio and others, 2002). Susceptibility depends on characteristics of the unsaturated zone, aquifer, and hydrologic conditions, and is independent of the chemical characteristics and sources of contaminants. Vulnerability depends on the sources and environmental behavior of contaminants in addition to the factors that affect recharge and ground-water flow. An area can have a low susceptibility to contamination, such as in Nevada where recharge rates are low. However, the same area can have a high vulnerability if contaminants are quickly flushed to the water table when water is applied by various land-use practices. DRASTIC (Aller and others, 1987) is commonly referred to as a method of evaluating aquifer vulnerability. DRASTIC stands for depth to water table (D), recharge (R), aquifer lithology (A), soil type (S), topographic slope (T), unsaturated zone lithology (I), and hydraulic conductivity of the aquifer (C). As defined in this report, DRASTIC is a method of evaluating aquifer susceptibility because it only considers natural factors affecting recharge and ground-water flow.

The hydrogeology of an area depends on many factors in addition to the hydrologic properties of the hydrogeologic units. An extreme perspective is that the hydrogeology of any area is unique because it will have a unique combination of factors that control the movement of water and contaminants through an aquifer. Another perspective is that some areas have similar hydrogeology because they have similar values for certain hydrologic variables, such as precipitation and soil permeability. Therefore, information from detailed studies in one area could be extrapolated to other areas of the state if there is an objective framework to transfer the information. The concept of hydrologic landscapes (Winter, 2001), which have similar values for selected hydrologic variables, provides this framework.

\section{Purpose and Scope}

The purpose of this report is to describe the hydrogeology and hydrologic landscape regions of Nevada. The description of the hydrogeology includes the lithology, horizontal hydraulic conductivity, soil permeability, and recent faulting of hydrogeologic units that comprise bedrock and alluvial aquifer systems, and how these features may affect the flow of ground water and movement of anthropogenic contaminants. Hydrologic landscape regions delineate areas of Nevada with similar mean annual precipitation, soil permeability, slope, aspect, and horizontal hydraulic conductivity.

\section{Acknowledgments}

The authors wish to acknowledge Michael Leigh of NDEP, Bureau of Mining Regulation and Reclamation, Russell Land and Arthur Ledger of NDEP, Bureau of Water Pollution Control, for providing access to State files that were used to compile estimates of horizontal hydraulic conductivity, and Michael Machette of the USGS, Geologic Hazards Team, Golden, Colorado, for providing a preliminary electronic copy of Quaternary and Tertiary faults in Nevada. 


\section{Previous Studies}

The first hydrologic classification of the Great Basin physiographic province was made by Synder (1962) who devised a scheme based on topography and degree of ground-water drainage. Most of Nevada lies within the Great Basin, except for small areas along the northern, western, and southern boundaries of the State. In the late 1960's, Cardinalli and others (1968) and Rush (1968), delineated hydrographic areas (HAs) for Nevada, based generally on topographic and drainage-area divides. HAs are different than hydrologic units (National Atlas of the United States, 1998) and are used for scientific and administrative purposes.

An HA can be either topographically closed or open. Open HAs have surface-water inflow or outflow, whereas closed HAs have no surface-water flow across their boundaries. The amount of ground-water drainage depends on the rock types underlying and bounding the HAs (fig. 1). HAs underlain and bounded by impermeable bedrock generally are undrained with no subsurface inflow or outflow, the water table beneath the valley floor is near land surface, and ground water is discharged by springs and evapotranspiration from phreatophytes and bare soil. Ground water can drain into and/or out of HAs underlain and bounded by permeable bedrock. In a completely drained HA, the water table beneath the valley floor may be so deep that all ground-water discharge is by subsurface outflow (Eakin and others, 1976, p. G3). All combinations of open, closed, undrained, partly drained, and completely drained HAs are found in Nevada.

Plume and Carlton (1988) grouped geologic formations and rock units into hydrogeologic units for the Great Basin using the geologic map of Nevada (Stewart and Carlson, 1978a). Plume and Carlton (1988) delineated 12 hydrogeologic units based on lithology, areal extent, estimated hydrologic properties, and age. Two basin-fill units include younger basinfill deposits of Holocene to Pliocene age and older basin-fill deposits of Pliocene to Miocene age. Consolidated-rock units include a volcanic-rock unit of lava flows and tuffs of Quaternary to Tertiary age, an intrusive-rock unit from Miocene to Late Triassic age, a marine-sedimentary unit and volcanic-rock unit of Early Miocene to Middle Triassic age, and a basement-rock unit of Precambrian age. In eastern Nevada, consolidated-rock units include two clastic-rock units, one younger (Late Permian to Late Devonian age) and one older (Early Cambrian to Late Precambrian age) than three carbonate-rock units which range in age from Late Triassic to Middle Cambrian.

Later, Plume (1996) simplified these 12 units into 6 hydrogeologic units with an emphasis on delineating basin-fill and carbonate-rock regional aquifer systems (Plume, 1996, p. B3, B11). In western Nevada, the simplified hydrogeologic units include younger basin-fill deposits, older basin-fill deposits, and a sedimentary- and igneous-rock unit. The sedimentary- and igneous-rock unit of western Nevada was considered a barrier to ground-water flow through the basin-fill aquifer system. In eastern Nevada, the simplified hydrogeologic units include another sedimentary- and igneous-rock unit, a carbonate- and clastic-rock unit, and a metamorphic-, igneous-, and sedimentary-rock unit (Plume, 1996, plate 2). The carbonate- and clastic-rock unit forms the carbonate-rock aquifer system of eastern Nevada. The metamorphic-, igneous-, and sedimentary-rock unit forms a barrier to ground-water flow through the carbonate-rock aquifer system.

The hydrogeology of southern Nevada also has been described in greater detail than the Great Basin. Winograd and Thordarson (1975, p. C14) delineated 10 hydrogeologic units near the Nevada Test Site including two clastic-rock confining units, two carbonate-rock aquifer units, five volcanic-rock units, and a basin-fill aquifer. These hydrogeologic units have

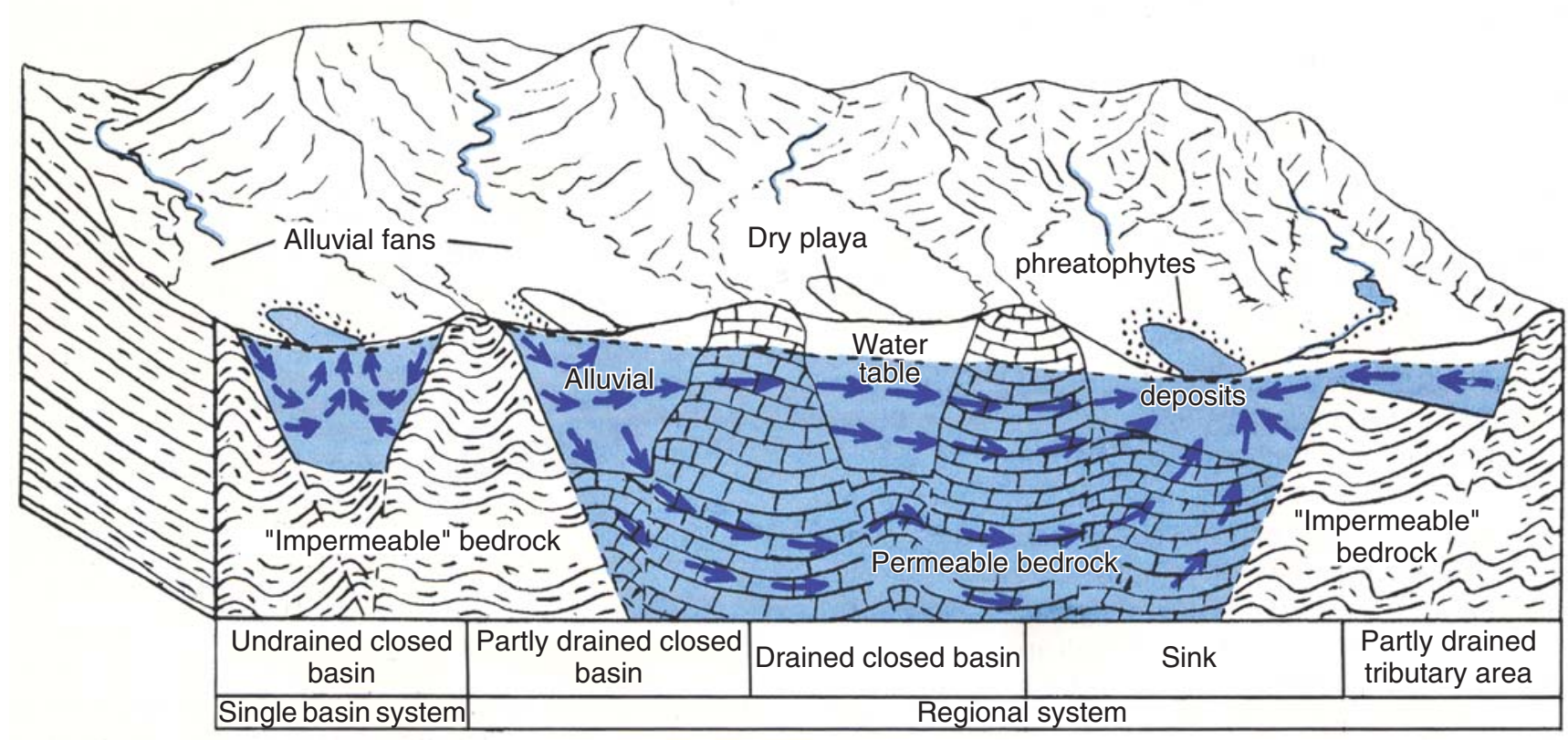

Figure 1. Ground-water flow characteristics for different types of hydrographic areas in Nevada. Modified from Eakin and others (1976, p. G10). 


\section{Hydrogeology and Hydrologic Landscape Regions of Nevada}

been used in more recent studies to delineate similar or additional hydrogeologic units in southern Nevada (Belcher and others, 2001, p. 6). D'Agnese and others (1997, p. 17) delineated 10 hydrogeologic units and D'Agnese and others (2002, p. 17) delineated 28 hydrogeologic units in the Death Valley region near southern Nevada. Other studies of the Death Valley ground-water flow system have delineated as many as 19 hydrogeologic units in the Death Valley flow system. The 19 hydrogeologic units were simplified into 11 units by Belcher and others (2001, table 1).

The concept of hydrologic landscapes was first proposed by Winter (2001). Hydrologic landscapes identify areas with similar hydrologic characteristics and form the basis for a conceptual framework to describe hydrologic processes. Wolock (2003) describes one approach of constructing hydrologiclandscape maps and how 20 hydrologic landscape regions were delineated for the United States. Lopes and Price (1997) used a similar approach to group metropolitan areas of the United States that have similar climate.

\section{Hydrogeologic Units}

The hydrologic properties of rocks and sediments vary over many orders of magnitude and often depend on localized geologic conditions such as fracture density and depositional environments. For these reasons, it is necessary to assume that rocks and sediments having similar lithology have similar hydrologic properties. Lithology is the characteristic of a rock or sediment, such as mineral content and grain size. Consolidated rocks that form mountain ranges and unconsolidated sediments that fill the basins between the ranges were grouped into hydrogeologic units having similar lithology and assumed to have similar hydrologic properties.

The geologic map of Nevada (Stewart and Carlson, 1978a), published at a scale of 1:500,000, is the primary source of lithology used to delineate hydrogeologic units. The Stewart and Carlson (1978a) map was compiled from 1:250,000-scale geologic maps of each county in Nevada and from other published and unpublished geologic maps produced at varying scales throughout the state (Stewart and Carlson, 1978b). Many of the geologic units mapped by Stewart and Carlson (1978a) contain rocks of varying lithology. In these cases, the first descriptor for the unit was considered to be the predominant lithology within the map unit. For a specific site, more detailed geologic and hydrologic data may be needed to obtain accurate estimates of hydrologic properties of surficial and subsurface materials.

The hydrologic properties most important in controlling the movement of fluids are hydraulic conductivity and porosity. Hydraulic conductivity is the rate at which water moves horizontally or vertically through rocks and sediments (Lohman and others, 1972, p. 4). The hydraulic conductivity of sediments generally is proportional to their grain size and degree of sorting, whereas the hydraulic conductivity of consolidated rocks depends, in large part, on their degree of fracturing. Porosity determines the volume of fluid that may be stored in the open pores of rocks and sediments. In general, the porosity of unconsolidated sediments is greater than that of consolidated rocks because pore spaces between sediment grains may be more numerous and more interconnected than pores in consolidated rock. However, consolidated rocks that typically have very low primary porosity may develop secondary porosity from open spaces along fractures and joints, or from dissolution of rocks along fractures and joints.

Consolidated rocks and unconsolidated sediments comprise the two major hydrogeologic units because their hydrologic properties are quite different. Plate 1 shows the distribution of consolidated rocks and unconsolidated sediments in Nevada. Consolidated rocks and unconsolidated sediments cover approximately equal areas in Nevada. Consolidated rocks are exposed over 56,108 mi2 (51 percent) of Nevada and unconsolidated sediments are exposed over $54,250 \mathrm{mi} 2$ (49 percent) of the state (table 1). These two major hydrogeologic units are further subdivided into more detailed hydrogeologic units based on lithology, horizontal hydraulic conductivity, slope, soil permeability, and mapped streamchannels. The hydrogeologic dataset is available at $<$ http://water.usgs.gov/lookup/getspatial?nv_hydgeolnv_p > .

\section{Consolidated-Rock Hydrogeologic Units}

Consolidated rocks are subdivided into 8 hydrogeologic units (table 1, plate 2) based on the lithologic descriptions of 97 mapped geologic units (Stewart and Carlson, 1978a;

Stewart, 1980) and on reported horizontal hydraulic conductivities (fig. 2, table 2). In order of decreasing area, the 8 consolidated-rock hydrogeologic units consist of Quaternary to Tertiary age volcanic flows of (1) basaltic, (2) rhyolitic, and (3) andesitic composition; (4) volcanic breccias, tuffs, and volcanic rocks older than Tertiary age; (5) carbonate rocks; (6) Tertiary-age consolidated and semi-consolidated tuffaceous rocks and sediments, (7) clastic rocks consisting of sandstone and siltstone; and (8) intrusive and metamorphic rocks.

The consolidated-rock hydrogeologic units are ranked in figure 2 and table 2 in approximate order of decreasing horizontal hydraulic conductivity reported by numerous investigators (app. 1). Reports and files from the USGS and NDEP were used for the compilation. References used were limited to those reporting values for aquifers in Nevada or within the Basin and Range physiographic province. As listed in appendix 1, the reported horizontal hydraulic conductivity values were derived from pumping aquifer tests using multiple or single wells, slug tests, laboratory tests of core materials, estimates based on the specific capacity of wells or numerical models, and from previous literature searches.

Quaternary to Tertiary age ( $<1$ to 43 million years [Ma]) volcanic flows were subdivided into basaltic, rhyolitic, and andesitic flows on the basis of their horizontal hydraulic conductivities (fig. 2, table 2). Volcanic flows are assumed to have relatively high horizontal hydraulic conductivity caused by development of fractures, joints, and shrinkage cracks during 
Table 1. Correlation of hydrogeologic units with geologic-map units of Stewart and Carlson (1978a)

\begin{tabular}{|c|c|c|}
\hline Hydrogeologic unit & $\begin{array}{c}\text { Geologic-map unit of } \\
\text { Stewart and Carlson (1978a) }\end{array}$ & $\begin{array}{l}\text { Area, } \\
\text { in square miles } \\
\text { (percent of total } \\
\text { area) }\end{array}$ \\
\hline \multicolumn{3}{|c|}{ Consolidated rock } \\
\hline $\begin{array}{l}\text { Quaternary to Tertiary-age volcanic flows__- Total } \\
\text { Basalt } \\
\text { Rhyolite } \\
\text { Andesite }\end{array}$ & $\begin{array}{l}\text { Qtb, Tba, Tb, Tbg } \\
\text { Qtr, Tr3, Tr2, Tr1 } \\
\text { Qta, Ta3, Ta2, Ta1 }\end{array}$ & $\begin{array}{l}15,584(14) \\
6,823(6) \\
4,749(4) \\
4,012(4)\end{array}$ \\
\hline $\begin{array}{l}\text { Volcanic breccias, tuffs, and volcanic rocks older } \\
\text { than Tertiary age }\end{array}$ & $\begin{array}{l}\text { Tbr, Tob, Tt3, Tt2, Tt1, Trt, Tts, TRk, TRPvs, } \\
\text { Msv, Jv }\end{array}$ & $13,656(12)$ \\
\hline Carbonate rocks & $\begin{array}{l}\text { Ml, PlPa, PlPcd, IPcd, Pc, PMc, Psc, PlPc, } \\
\text { lPc, Mc, St, Dc, DCc, Sc, Soc, TRc, MDmc, MDs, } \\
\text { Dt, Ot, OCc, OCt, Oc, Cc }\end{array}$ & $10,085(9)$ \\
\hline Tertiary tuffacious rocks and sediments & QTs, Ts3, Ths, Tksu, Ts2, Ts1 & $6,493(6)$ \\
\hline Clastic rocks & $\begin{array}{l}\text { TKs, Ks, Jd, Jgb, JTRa, TRmt, TRPd, Css, } \\
\text { JTRs, TRch, JPu, TRPs, PMh, DCsv, Dsl, } \\
\text { Ds, Se, Ss, Osv, Os, Ch, Csc, Ct, CZs, Zw, } \\
\text { CZq, Zqs }\end{array}$ & $5,630(5)$ \\
\hline Intrusive and metamorphic rocks & $\begin{array}{l}\text { JTRsv, Tri, Tmi, Ti, TJgr, Tgr, MZgr, Kgr, } \\
\text { KJd, Jgr, TRgr, KJim, TRlgr, PZsp, Ygr, Xm }\end{array}$ & $4,660(4)$ \\
\hline Consolidated rock-Total & & $56,108(51)$ \\
\hline \multicolumn{3}{|c|}{ Unconsolidated sediments } \\
\hline Alluvial slope & -- & $33,733(31)$ \\
\hline Valley floor & -- & $13,976(13)$ \\
\hline Playas & Qp & $5,002(4)$ \\
\hline Fluvial deposits & -- & $1,539(1)$ \\
\hline Unconsolidated sediments-Total & Qa, Qp, Qls, Qm, Qtoa & $54,250(49)$ \\
\hline
\end{tabular}

solidification of the flows (Davis and DeWiest, 1966, p. 337). Basaltic rocks often have a high porosity from open vesicles formed by gasses entrained in the molten lava, but also may be quite dense with low porosity. Basaltic rocks may form aquifers with close to the greatest horizontal hydraulic conductivity known (Davis and DeWiest, 1966, p. 333; Plume, 1996, p. B20). Of the Tertiary volcanic flows, rhyolitic flows are somewhat less permeable than basaltic flows and andesitic flows are least permeable (table 2). Ground-water flow between several basins in Nevada has been found to occur through volcanic flows of Tertiary age (Handman and others, 1990, p. 53; Maurer, 1993, p. 21; Maurer, Plume, Thomas, and Johnson, 1996, p. 34; Harrill and Preissler, 1994, p. 11). All three types of volcanic flows are found in association with each other in northern Nevada, generally north of the Humboldt River, along the western boundary of the State, and at scattered locations throughout the remainder of the State (plate 2). Volcanic flows in the northwestern corner of Nevada are part of the Modoc Plateau that extends into northeastern California (Macdonald, 1966, p. 65). Volcanic flows along the northern boundary of the state are part of the Owyhee Upland that bounds the southern Snake River Plain (Stewart, 1980, p. 7).

Volcanic breccias, tuffs, and older volcanic rocks consist of Tertiary-age breccias and welded to non-welded tuffs, and older volcanic rocks ranging from Jurassic to Triassic in age (138 to $240 \mathrm{Ma}$ ). These rocks are assumed to have low to moderate horizontal hydraulic conductivity. Welded tuffs locally form aquifers near the Nevada Test Site and may have a great 


\section{Hydrogeology and Hydrologic Landscape Regions of Nevada}

Table 2. Range in horizontal hydraulic conductivity for hydrogeologic units. See Appendix 1 for detailed information on hydraulic conductivity

\begin{tabular}{|c|c|}
\hline Hydrogeologic unit & $\begin{array}{l}\text { Range in horizontal } \\
\text { hydraulic } \\
\text { conductivity } \\
\text { (feet per day) }\end{array}$ \\
\hline \multicolumn{2}{|c|}{ Consolidated Rock } \\
\hline Carbonate rocks & $3 \times 10^{-5}$ to 3,300 \\
\hline $\begin{array}{l}\text { Quaternary to Tertiary-age volcanic flow } \\
\text { Basalt } \\
\text { Rhyolite } \\
\text { Andesite }\end{array}$ & $\begin{array}{l}2 \times 10^{-4} \text { to } 1,300 \\
2 \times 10^{-5} \text { to } 260 \\
2 \times 10^{-4} \text { to } 60\end{array}$ \\
\hline $\begin{array}{l}\text { Volcanic breccias, tuffs, and volcanic } \\
\text { rocks older than Tertiary-age }\end{array}$ & $3 \times 10^{-7}$ to 600 \\
\hline Intrusive and metamorphic rocks & $7 \times 10^{-8}$ to 30 \\
\hline Tertiary tuffaceous rocks and sediments & $2 \times 10^{-4}$ to 20 \\
\hline $\begin{array}{l}\text { Clastic rocks } \\
\text { Sandstone } \\
\text { Siltstone }\end{array}$ & $\begin{array}{l}7 \times 10^{-4} \text { to } 18 \\
2 \times 10^{-9} \text { to } 16\end{array}$ \\
\hline \multicolumn{2}{|c|}{ Unconsolidated Sediment } \\
\hline Fluvial deposits & 4 to 2,200 \\
\hline Basin-fill undifferentiated & $1 \times 10^{-3}$ to 590 \\
\hline $\begin{array}{l}\text { Alluvial slope } \\
\text { Upper } \\
\text { Lower } \\
\text { Undifferentiated }\end{array}$ & $\begin{array}{c}0.5 \text { to } 140 \\
0.02 \text { to } 140 \\
2 \times 10^{-4} \text { to over } 150\end{array}$ \\
\hline Valley floor & 2 to 90 \\
\hline Playa & $3 \times 10^{-5}$ to 2 \\
\hline
\end{tabular}

horizontal hydraulic conductivity (Harrill and Prudic, 1998, p. A19; D'Agnese and others, 1997, p. 19). However, rock units mapped as welded tuffs by Stewart and Carlson (1978a) also include non-welded tuffs, and the horizontal hydraulic conductivity of the mapped units as a whole is probably low to moderate. Older volcanic rocks are assumed to have low to moderate horizontal hydraulic conductivity caused by weathering and filling of pores with secondary minerals (Davis and DeWiest, 1966, p. 337). This assumption is substantiated by Stewart and Carlson (1978a) who describe many of the older volcanic rocks as altered and Plume (1996, p. 20) who notes that older volcanic rocks that have been extensively tested near the east-central part of the State have a low horizontal hydraulic conductivity. This hydrogeologic unit forms a northwest/southeast trending band from north of Las Vegas to near the center of Churchill County (plate 2). Tertiary-age volcanic tuffs associated and interbedded with Tertiary-age volcanic flows also are exposed along the northern part of Nevada (Stewart, 1980, p. 92, 98, 102).

Carbonate rocks consisting of limestone, dolomite, and units mapped as mixtures of limestone and clastic rocks by Stewart and Carlson (1978a) range in age from Permian to Cambrian (240 to $570 \mathrm{Ma}$ ). These rocks generally have great horizontal hydraulic conductivity caused by fractures and joints that have been widened by dissolution, forming open channels ranging in width from inches to tens of feet (Plume, 1996, p. B11). Drill logs of deep petroleum exploration wells indicate that fractured zones of high horizontal hydraulic conductivity and porosity in carbonate rocks range in thickness from a few tens of feet to usually not more than $100 \mathrm{ft}$, separated by unfractured rocks of low horizontal hydraulic conductivity and porosity hundreds to thousands of feet thick (Plume, 1966, p. B12). Carbonate rocks form a regional aquifer system in the eastern and southern part of the State, where ground water flows for hundreds of miles beneath many basins (Harrill and Prudic, 1998, p. 28-35).

Tertiary tuffaceous rocks and sediments range from consolidated to semi-consolidated and are mostly fine-grained with low horizontal hydraulic conductivity. They consist of sediments deposited in lacustrine, fluvial, and aeolian settings that have variable degrees of consolidation. Tuffaceous rocks and sediments are of Tertiary age (6 to $43 \mathrm{Ma}$; Stewart, 1980, p. 87-93). At various locations they also contain lenses of gravel, conglomerate, sandstone, siltstone, lava flows, ash-flow tuffs, and limestone (Stewart, 1980, p. 87-89). The sediments were deposited in down-faulted basins that were the precursors, but not necessarily the same configuration, of present-day basins in Nevada (Stewart, 1980, p. 92). They comprise a large part of the basin-fill sediments in the northeastern part of Nevada (plate 2), and include sequences of volcanic tuffs in the northwestern part of the State (Stewart, 1980, p. 92; Stewart and Carlson (1978a). Plume (1996, p. B15) notes that they probably underlie younger, unconsolidated basin-fill sediments in most valleys.

Clastic rocks consist of sandstone, siltstone, and shale from Cretaceous to Precambrian age (63 to more than $570 \mathrm{Ma}$ ). These rocks are assumed to have low to moderate horizontal hydraulic conductivity and porosity, although they are considered barriers to ground-water flow where they are interbedded or in contact with rocks of greater permeability (Harrill and Prudic, 1998, p. A19; Davis and DeWiest, 1966, p. 347; D'Agnese and others, 1997, p. 20). Table 2 shows that sandstone is somewhat more permeable than siltstone. The permeability of sandstone is one to three orders of magnitude less than that of unconsolidated sediments of similar grain size due to cementation by clay minerals, calcite, or silica (Davis and DeWiest, 1966, p. 350-351). The porosity of sandstone has been shown to decrease with depth (Freeze and Cherry, 1979, p. 152). Because of the low solubility of most clastic rocks, secondary porosity from solution is not developed, and 


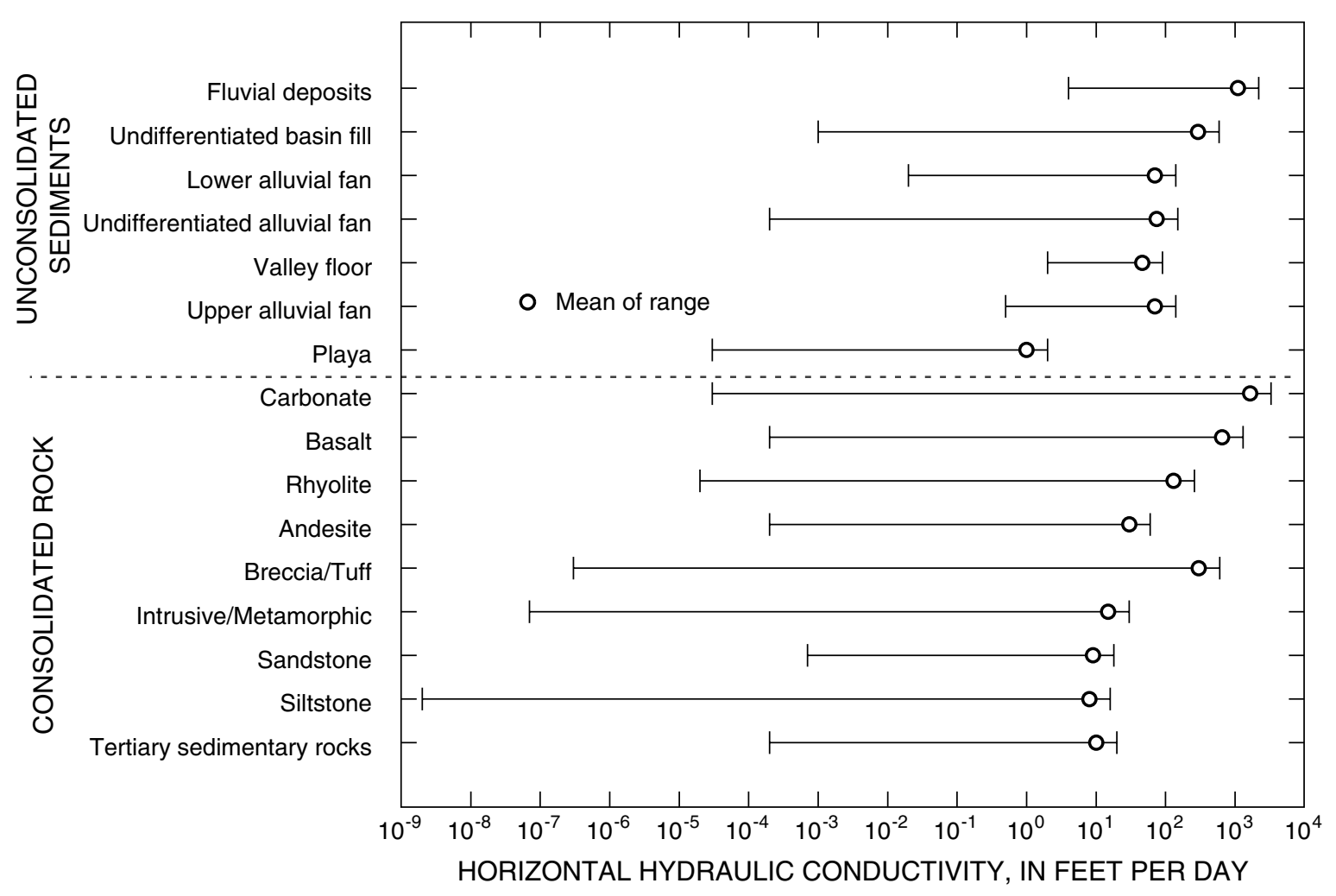

Figure 2. Range in horizontal hydraulic conductivity for hydrogeologic units.

fractures may become sealed by plastic deformation of sandstone and interbedded siltstone (D'Agnese and others, 1997, p. 20). Clastic rocks are exposed in a northwest/southeast trending band from north-central Nye County to central Humboldt County, in Esmeralda County, and in association with carbonate rocks in the eastern and southern parts of the state (plate 2). Clastic rocks generally are siltstone and shale in northern Nevada. Sandstone is exposed mainly in Clark and southern Lincoln Counties (Stewart, 1980, p. 23, 27, 31, 34, $43,48,62,74)$.

Intrusive and metamorphic rocks range in age from Jurassic to Precambrian. Igneous intrusive rocks cooled underground and generally are less fractured than volcanic flows. Igneous intrusive rocks mainly are granodiorite and quartz monzonite, similar in composition to the Sierra Nevada batholith (Stewart, 1980, p. 73-76). Metamorphic rocks are of sedimentary or volcanic origin and have been subjected to high temperatures, pressures, or both. Igneous and metamorphic rocks have low horizontal hydraulic conductivity and low porosity, except where fractured or faulted. Freeze and Cherry (1979, p. 159-160) note that the horizontal hydraulic conductivity of intrusive rocks greatly decreases at more than 100 to $200 \mathrm{ft}$ below land surface as overburden pressures cause fractures to close. Prudic and others (1995, p. 11) note that these rocks generally act as barriers to regional ground-water flow through carbonate rocks. Intrusive and metamorphic rocks are exposed mainly in the western half of Nevada with widely scattered exposures in the eastern half.

\section{Unconsolidated-Sedimentary Hydrogeologic Units}

Unconsolidated sediments that fill the basins between the mountain blocks comprise the most used aquifers in Nevada and range in age from Pliocene (6 Ma) to recent. The majority of sediments are of Quaternary age ( $<2 \mathrm{Ma}$; plate 1; Stewart, 1980, p. 93). Unconsolidated sediments mapped by Stewart and Carlson (1978a) were subdivided into four hydrogeologic units on the basis of ground-water flow regime, topographic slope, and mapped stream channels to provide more detailed hydrologic information on basin-fill sediments. The four unconsolidated-sedimentary hydrogeologic units are alluvial slopes, valley floors, fluvial deposits, and playas. Available estimates of horizontal hydraulic conductivity for these geomorphic features are summarized in figure 2 and table 2 with detailed estimates listed in appendix 1.

After water and contaminants move past the soil horizon, their movement is controlled by the permeability of sediments underlying alluvial slopes and the valley floors. In general, sediments forming alluvial slopes are coarse-grained and poorly sorted with relatively few interbedded clay layers (Plume, 1996, p. B16-B17; Bedsun, 1980; Mifflin, 1988, p. 71; Anderson and others, 1983, p. 1059). The grain size of basin-fill sediments decreases towards the center of the valley (Plume, 1996, p. B15; Davis, 1988, p. 286), and the lower parts of alluvial slopes are likely to interfinger with layers of well sorted sand, silt, and clay deposited on the valley floor (Plume, 1996, p. B15; Bedsun, 1980). Basin-fill sediments on the valley floor may contain 


\section{Hydrogeology and Hydrologic Landscape Regions of Nevada}

individual layers with high horizontal and vertical hydraulic conductivity, but the overall vertical hydraulic conductivity is relatively low because of the interbedded clay layers. Johnson and others (1968, table 5) report vertical hydraulic conductivities of valley-floor sediments in central California that range from $9 \times 10^{-6} \mathrm{ft} / \mathrm{d}$ for clay layers to $90 \mathrm{ft} / \mathrm{d}$ for sand layers. Harrill and Prudic (1998, p. 55) report vertical hydraulic conductivities that range from one to three orders of magnitude less than horizontal hydraulic conductivities used for modeling five alluvial basins in and near Nevada. Thus, the potential for vertical flow of fluids through unconsolidated sediments is likely greater on alluvial slopes than on the valley floor.

Most ground-water recharge occurs on alluvial slopes from infiltration of precipitation and streamflow from mountain-blocks, resulting in generally downward ground-water flow (Mifflin, 1988, p. 76). On the valley floor, little groundwater recharge occurs and ground-water flow generally is parallel to land surface or upward where it discharges by evapotranspiration from plants and bare soil (Mifflin, 1988, p. 76; Freeze and Cherry, 1979, p. 145 and 193-194). In addition, water-table gradients that drive lateral ground-water flow generally are greater beneath alluvial slopes, ranging from 0.02 to 0.005 , whereas beneath the valley floor they range from 0.002 to $6 \times 10^{-7}$ (Handman and Kilroy, 1997, p. 61; Harrill and Preissler, 1994, p. 10; Maurer, 1986, p. 17; Prudic and Herman, 1996, p. 16; Thomas and others, 1989, pl. 2). These generalized descriptions of ground-water flow may vary somewhat depending on the permeability of consolidated rocks forming the mountain block and the amount of annual precipitation, but are applicable to all valleys in Nevada (fig. 3).

These distinctions in flow regime have direct implications for aquifer susceptibility. Contaminants released on alluvial slopes compared to valley floors are more likely to spread quickly through large areas and reach deep aquifers because ground-water flow is downward and vertical hydraulic conductivity, recharge, and water-table gradients are relatively high. Contaminants released on valley floors compared to alluvial slopes are more likely to spread slowly through small areas of shallow aquifers because ground-water flow is either parallel to land surface or upward and the recharge rate, vertical hydraulic conductivity, and water-table gradient are relatively low. Typically, deep aquifers are used for municipal supply and shallow aquifers are used for domestic supply.

Because of the different flow regimes, topographic slope was used to divide unconsolidated sediments into two major groups-alluvial slope and valley floor. Alluvial slopes are reported to have a wide range of topographic slope. Motts and others (1970, p. 10) report average alluvial slopes of 3.5 to 5 percent ( 2 to 3 degrees); the reported slopes of ten alluvial slopes in Nevada range from 1.6 to 7.1 percent (1 to 4 degrees; French, 1987, p. 200); the lower parts of alluvial slopes in Death Valley range from 1.3 to 6.2 percent ( 0.7 to 3.5 degrees; Denny, 1965, p. 42-49); Abrahams and Parsons (1994, p. 329) cite a range of 3.5 to 7 percent ( 2 to 4 degrees) for alluvial slopes in the southwestern United States; and Peterson (1981, p. 8) cites about 1 percent ( 0.6 degrees) as the point where alluvial slopes merge with the valley floor in the Basin and Range province. The lower parts of alluvial slopes are most likely to interfinger with finer-grained sediments of the valley floor (Plume, 1996, p. B15; Bedsun, 1980). Thus, a slope somewhat greater than the lower values reported for alluvial slopes is probably reasonable to delineate alluvial slopes from valley floors. The average of the 5 values for lower alluvial slopes is 2.2 percent. For this study, areas with a slope greater than 3 percent (1.7 degrees) were designated as alluvial slope, and areas with a slope of less than 3 percent were designated as valley floor.

The 3-percent slope break was determined using the National Elevation Dataset, which is a $100-\mathrm{ft}(30-\mathrm{m})$ resolution digital-raster elevation dataset based primarily on USGS 7.5 minute digital elevation models. Using a geographic information system, 100-ft (30-m) cells with slopes less than 3 percent were distinguished as a first approximation of the valley floor. A line was then digitized around the first approximation to refine the alluvial slope/valley floor contact. The digitized line was overlain on Landsat Thematic Mapper satellite images at a scale of 1:100,000 to check the position of the alluvial slope/valley floor contact. For most of Nevada, the contact provides a reasonable delineation of alluvial slopes and valley floors (plate 2).

Alluvial slopes are almost 2.5 times the area of valley floors in Nevada. Visual inspection of plate 2 and calculated percentages of consolidated rock, alluvial slope, and valley floor for each HA shows that valley floors comprises the largest percentage of the HAs in central and western Nevada, and alluvial slopes comprise the largest percentage of HAs in southern Nevada. The high percentage of alluvial slopes in southern Nevada could be due to a combination of diminished tectonic activity in southern Nevada with erosion as a dominant geologic process (Best and Hamblin, 1978; p. 331) and the small basin size, resulting in alluvial slopes from surrounding mountains that coalesce in the center of the basin. Consolidated rocks comprise the largest percentage of HAs in northwestern and northern Nevada, which corresponds to Tertiary-age volcanic flows of the Modoc Plateau and the Owyhee Upland.

Playas, mapped by Stewart and Carlson (1978a; plate 2), form at the lowest altitudes of many basins in Nevada. Playas typically are devoid of vegetation and often consist of finegrained sediments that were deposited in lakes that occupied many valleys of Nevada during the Pleistocene epoch (10 thousand years [Ka]) to $1.6 \mathrm{Ma}$; Stewart, 1980, p. 97). However, Motts and others (1970, p. 14) describe a few coarsegrained playas that consist of sand and silt-sized sediments. Examples are the playas in the Rhodes and Columbus Salt Marsh Valleys and Clayton Valley playas in southwestern Nevada, which have moderate to great soil permeability (5 to $20 \mathrm{ft} / \mathrm{d}$; plate 3; HAs 118, 119, and 143). The water table beneath coarse-grained playas generally is coincident with the playa surface, and ground-water discharge commonly produces evaporites (Motts and others, 1970, p. 14).

Because of their hydrologic significance, active stream channels were mapped and superimposed on all hydrogeologic units. As reported by Plume (1996, p. B18) and Bredehoeft 
A

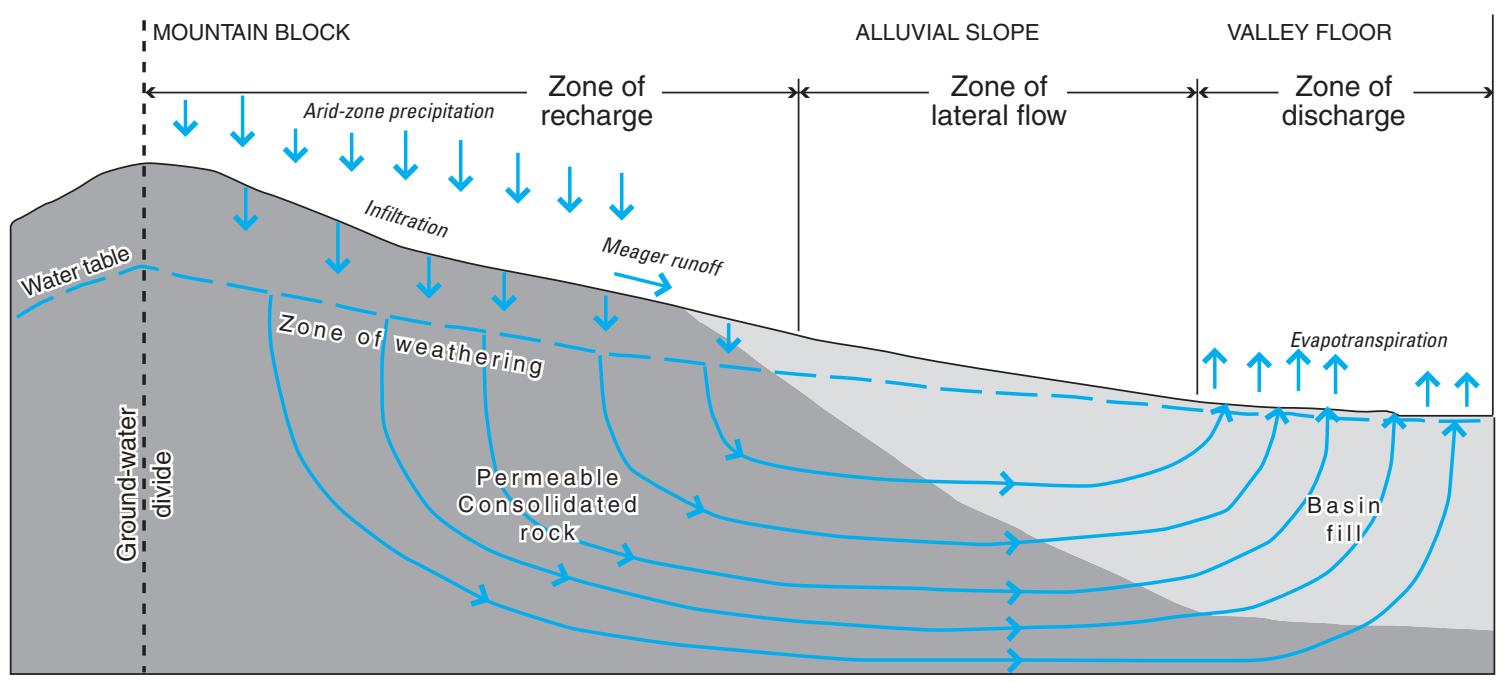

$B$

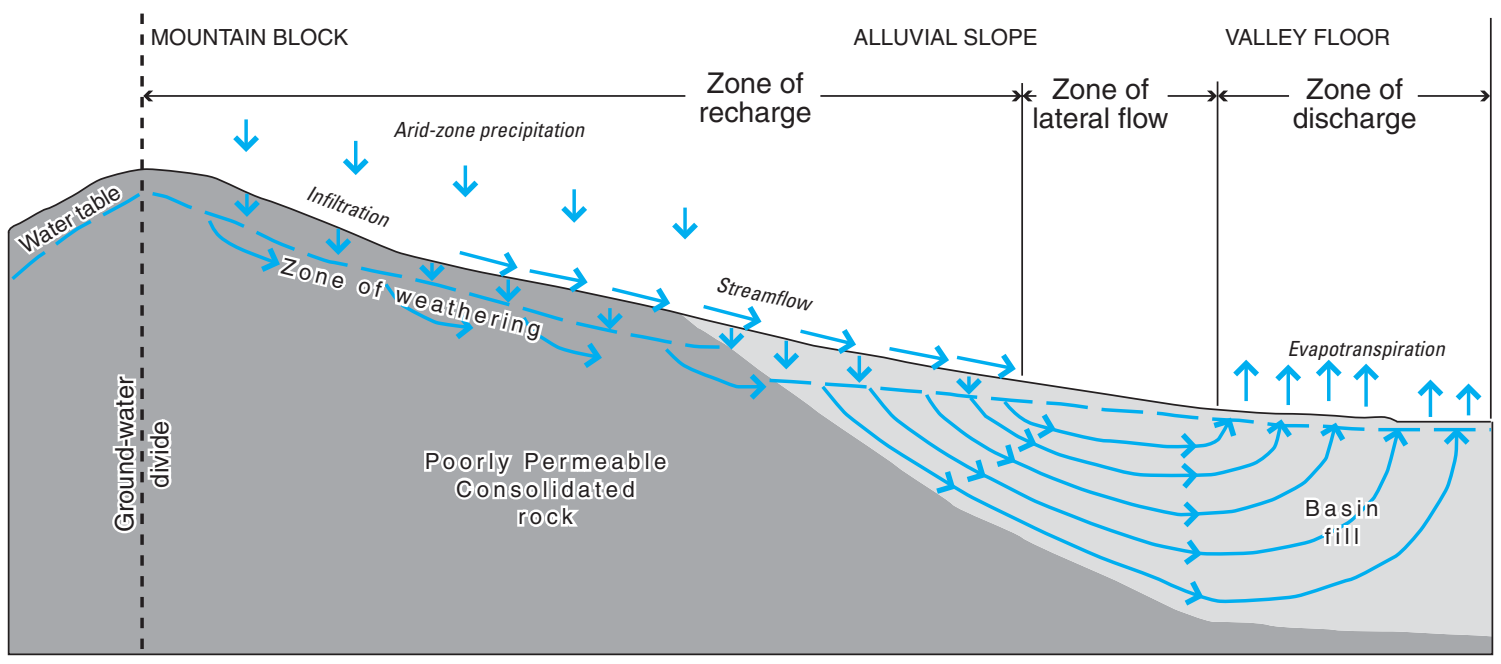

C

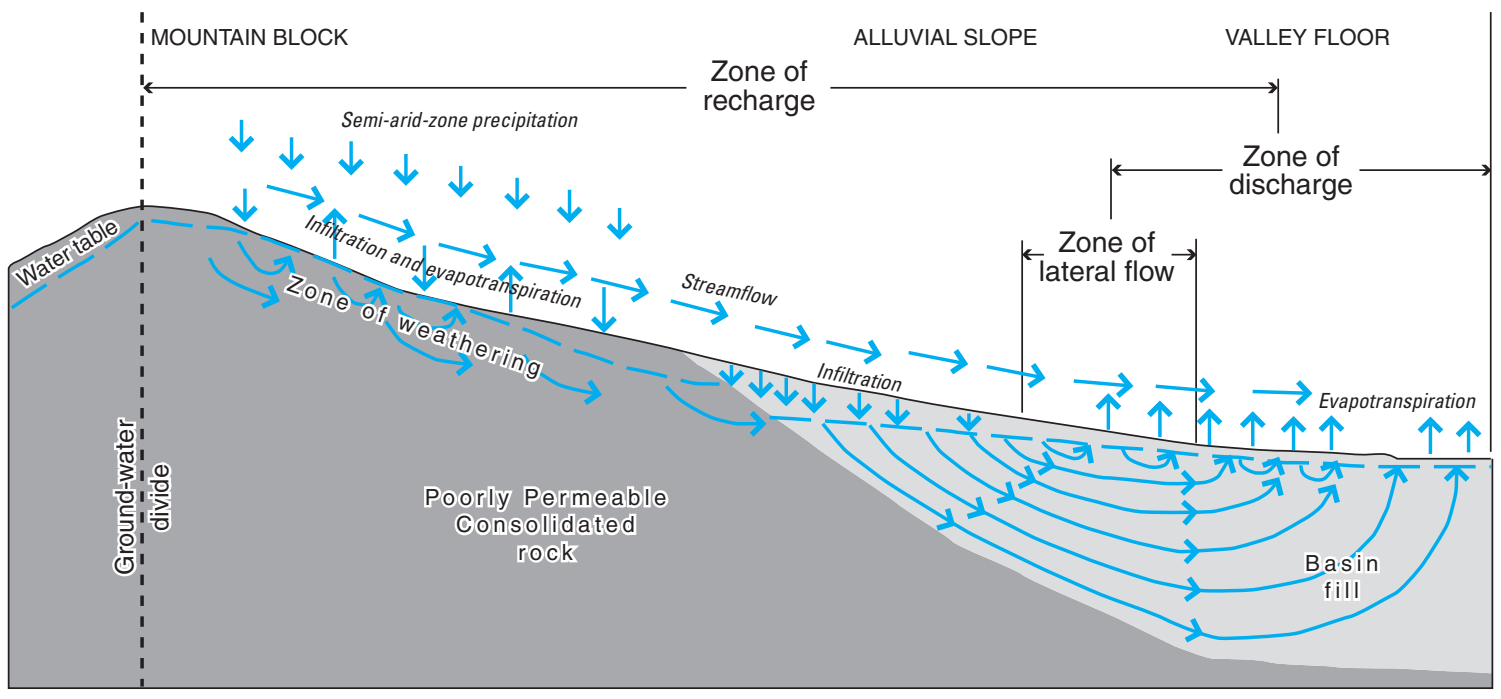

Modified from Berger (2000, p.7)

Figure 3. Typical ground-water flow patterns perpendicular to the long axis of valleys in Nevada for mountain blocks with different permeability and annual precipitation. Modified from Berger (2000, p. 7). $A$, arid precipitation on permeable consolidated rock. $B$, Arid precipitation on poorly permeable consolidated rock. $C$, semi-arid precipitation on poorly permeable consolidated rock. 
(1963, p. 28) and shown in table 3, sediments deposited by streams, commonly called fluvial deposits, may have significantly greater permeability than those of alluvial-slope or valley-floor deposits because of their high degree of sorting and coarse texture. Fluvial deposits represent zones of potentially high horizontal hydraulic conductivity and preferred pathways for contaminants. Fluvial deposits are easily recognized by braided-stream patterns on aerial photographs (Bredehoeft, 1963, p. 28).

For this study, Landsat Thematic Mapper images taken from April to June 2000 were used to determine the location and approximate width of recently active stream channels. Active stream channels were recognized as roughly linear or braided features lacking vegetation as observed at a scale of 1:100,000. The 1:100,000-scale hydrography digital line graph data (U.S. Geological Survey, various dates) was overlain on Landsat images, and stream segments corresponding to active stream channels were assigned the measured width. Stream-channel widths measured from the Landsat images were checked by field verification and found to be reasonably accurate. During field verification, it was found that a large part of the channel that appeared active from the Landsat images was actually covered by fine-grained sediments. The fine-grained sediments likely were deposited after recession of sediment-laden high flows in the stream channels, and their lateral extent marks the stream's active flood plain. Despite the presence of finegrained sediments near land surface, the mapped fluvial deposits (plate 2) likely represent areas where well-sorted fluvial sediments are present at depth. Over geologic time as the basins filled with sediments, stream channels have migrated laterally across the valley floor or lower alluvial slope (Plume, 1996, p. B15; Bedsun, 1980, p. 51), and old stream-channel deposits may be present in areas not shown as active channels in plate 2. For this reason, the mapped fluvial deposits should be considered only as generalized areas having potential for rapid ground-water flow parallel to the direction of the channel.

\section{Soil Permeability}

The movement of water and contaminants into the subsurface is first controlled by the permeability of soils that develop in the upper several feet of unconsolidated sediments and consolidated rocks. Soil permeability was estimated from a compilation of soil properties by Schwarz and Alexander (1995). The compilation used values for individual soil layers to calculate weighted averages of permeability and other properties of mapped soils for the entire thickness or to a depth of 60 inches, whichever was less. In Nevada, soil thickness from Schwarz and Alexander (1995) and slope from the National Elevation Dataset is significantly and inversely correlated with slope (correlation coefficient -0.75 ). Soil thickness decreases from about 60 inches, the maximum thickness measured, on flat slopes to about 30 inches on 40-percent slopes. Average soil permeability in Nevada ranges from about 0.02 to $30 \mathrm{ft} / \mathrm{d}$. Average soil permeability was grouped into five descriptive categories ranging from very high to very low (table 3 ; plate 3 ). The limits of soil permeability for descriptive categories are arbitrary, but were selected so that they provide a reasonable match to geomorphic features in unconsolidated-sedimentary units such as playas, alluvial slopes, flood plains, and stream channels mapped by various investigators (Stewart and Carlson, 1978a; Stewart and McKee, 1977; Cohen, 1963; Bredehoeft, 1963; Johnson, 1977; Tschanz and Pampeyan, 1970).

Table 3. Range in soil permeability for descriptive categories of unconsolidated sediments and corresponding geomorphic features

\begin{tabular}{lll}
\hline $\begin{array}{c}\text { Descriptive } \\
\text { category }\end{array}$ & $\begin{array}{c}\text { Soil } \\
\text { permeability } \\
\text { feet per day) }\end{array}$ & \multicolumn{1}{c}{$\begin{array}{c}\text { Corresponding } \\
\text { geomorphic } \\
\text { feature }\end{array}$} \\
\hline Very high & 20 to 30 & Alluvial slope/dune sand \\
High & 10 to 20 & Alluvial slope/stream channel \\
Moderate & 5 to 10 & Valley-floor alluvium \\
Low & 1 to 5 & Flood plain/lake deposits \\
Very low & 0.02 to 1 & Playa \\
\hline
\end{tabular}

In general, soil permeability is low to moderate in northern, northeastern, and eastern Nevada and high to very high in western, southwestern, and southern Nevada (plate 3 ). The type of parent rock and climate are factors that likely cause these spatial patterns. Granitic rocks and tuffaceous volcanic rocks of western and southwestern Nevada (plate 2) are more likely to produce sandy, permeable soils than other types of parent rock (Candland, 1984, p. 271; Buol and others, 1973, p. 111-113). Granitic and tuffaceous rocks have a high percentage of quartz, which does not weather into clay minerals. In contrast, weathering of basaltic and andesitic volcanic rocks, siltstones, and shales in northern and northeastern Nevada generally produce clayey soils with low permeability (Buol and others, 1973, p. 110-112). Ascribing likely soil types formed from carbonate rocks is difficult in Nevada because carbonate rocks of differing ages and lithology are exposed near each other. Stewart (1980) describes carbonate rocks of Ordovician, Devonian, and Pennsylvanian/Permian age that are relatively sandy (Stewart, 1980, p. 25, 32, and 46). Carbonate rocks of Cambrian, Silurian, and Mississippian age are siltier and interbedded with shale (Stewart, 1980, p. 17, 29, and 41). Stewart (1980 p. 17-22) describes a limestone and shale province along the western edge of the carbonates where deposition likely occurred in deeper water, producing rocks with a greater silt content. Sandy carbonate rocks are likely to form sandy soils and silty carbonate 
rocks are likely to form clayey soils (Buol and others, 1973, p. 110). Buol and others (1973, p. 126) also note that greater rainfall produces more clayey soils, which would accelerate the weathering process in relatively wet northern Nevada.

In addition to parent rock-type and climate, eolian deposition of sediments from quartz-rich parent rocks has produced highly permeable sand-dune complexes covering large areas of many valleys in the western and southwestern parts of the state. Notable examples are southern Desert and Silver State Valleys (plate 3, HAs 31 and 32), Pyramid and Winnemucca Lake Valleys (HAs 80 and 81), the Carson Desert (HA 101), Fish Lake Valley (HA 117), and Amargosa Valley (HA 230).

In most valleys, soil permeability is greatest near the margins of the valley and decreases toward the valley floor (plate 3). This is likely due to sorting of sediments as stream velocity decreases from the alluvial slopes toward the center of the valleys (Plume, 1996, p. B15; Davis, 1988, p. 286; Rust and Koster, 1984, p. 55). Coarse, sandy sediments are deposited on the alluvial slopes as streams emerge from mountainous canyons and fine, clayey sediments are transported further down valley (Plume, 1996, p. B15; Davis, 1988, p. 286), which could result in the decrease in soil permeability. Notable exceptions to this general trend are several valleys about 40 miles north of Las Vegas. Soils near the center of these valleys have very high permeability (plate 3, HAs 161, 168, 169B, 211, and 216).

Another important soil characteristic in controlling vertical flow is the presence of a hardpan within the soil profile. Areas in unconsolidated sediments where soils have developed a continuous hardpan greater than 3-in. thick or where hardpan is more than 18-in. thick and discontinuous or fractured are shown on plate 3 . In general, hardpan forms near exposures of carbonate rocks in the eastern part of the State (plate 2). Vertical flow may be restricted by hardpan in these areas.

\section{Faulting and Ground-Water Flow}

Another geologic factor that may affect ground-water flow is the offset of aquifer materials along faults. In unconsolidated sediments, a fault zone can have a horizontal hydraulic conductivity that is three orders of magnitude less than the parent material (Goodwin and others, 1999, p. 2). Movement along the fault can juxtapose sand and clay layers and create gouge, which is a zone of finely ground or mixed sediments along the fault plane (Heynekamp and others, 1999, p.27). In addition, Heynekamp and others (1999, p. 41) note that cementation often occurs on the basin-ward side of faults in coarse-grained sediments, further reducing the permeability of the fault zone. Thus, faults in unconsolidated sediments usually are barriers to ground-water flow, which could force contaminated ground water to land surface in spring discharge. However, Sigda and others (1999, p. 67) note that fine-grained fault gouge may act as a capillary conduit through the unsaturated zone to the water table.
In low-porosity consolidated rocks, the fault plane typically is surrounded by a wide zone of fractures. Within the fault plane, gouge can develop and reduce the horizontal hydraulic conductivity relative to the parent material and fracture zone. In the fracture zone, horizontal hydraulic conductivity is high relative to the parent material (Goodwin and others, 1999, p. 1-2; Caine and Forster, 1999, p. 102). Thus, in consolidated rocks, ground-water flow is reduced in directions normal to the fault zone and increased in directions parallel to the fault zone (Caine and Forster, 1999, p. 124; McKee and others, 1998, p. 8). With time, carbonate and silica minerals can precipitate in the fractures and can reduce ground-water flow (Antonellini and others, 1999, p. 24). However, continued faulting may form new fractures so that a fault may cycle between a zone of preferred flow and a flow barrier (Nelson and others, 1999, p. 69). Faunt (1997, p. 30) states that faults in areas of extentional stress fields are likely to be open to ground-water flow, whereas those in compressional stress fields are likely to be closed to ground-water flow. A detailed analysis of stress fields, faults, and ground-water flow in southern Nevada was compiled by Faunt (1997). However, such an analysis for the entire State is beyond the scope of this study. Figure 4 shows the potential effects of faults for various combinations of permeability of faulted aquifer materials and fault zones.

Large-scale faulting occurred in east-central Nevada during the Antler orogeny (360-365 Ma), in central Nevada during the Sonoma orogeny (200-215 Ma), and at various times and locations during the Mesozoic era (66-240 Ma; Stewart, 1980, p. 36, 55, and 76-87). Many of the large-scale faults were thrust faults, which moved large blocks of rock up to 90 miles over underlying rocks (Stewart, 1980, p. 36, 57, 77, 79, 84). Other types of faults include strike-slip faults that laterally offset aquifer materials and normal faults that offset aquifer materials in a vertical direction. Many of these faults are inactive. However, the juxtaposition of different rock types may greatly affect ground-water flow, especially in carbonate-rock aquifers (Plume, 1996, p. B24; McKee and others, 1998, p. 1).

Faulting that produced the present-day Basin-and-Range topography began about $17 \mathrm{Ma}$ (Stewart, 1980, p. 110). The faults generally are steeply dipping normal faults that uplifted mountain blocks (horsts) and down-dropped the valley floors (grabens) (Stewart, 1980, p. 110). The faults were produced by extension of the earth's crust beneath the Basin and Range physiographic province and have vertical offsets as great as 6,000 to $15,000 \mathrm{ft}$ (Stewart, 1980, p. 110). Along southwestern Nevada from Las Vegas to north of Reno, right-lateral strike-slip faulting occurs in a wide zone known as the Walker Lane. Lateral offsets as much as 20 mi have been suggested along the Walker Lane (Stewart, 1980, p. 115). Recent and historic movement along both normal and strike-slip faults show that the region is still tectonicly active (Stewart, 1980, p. 117).

Faults that were determined to have movement in the Quaternary period ( $<2 \mathrm{MA})$ are shown on plate 1 , as compiled by the U.S. Geological Survey (2003). Many long faults are coincident with or near the contact between consolidated rocks and unconsolidated sediments. In comparison, faults in unconsolidated 


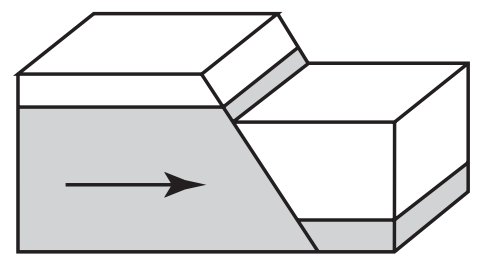

OPEN FAULT-Springs along fault or flow changes direction along fault; depending on permeability contrast, there may be a large drop in head

CLOSED FAULT_Springs or diffuse discharge upstream from fault

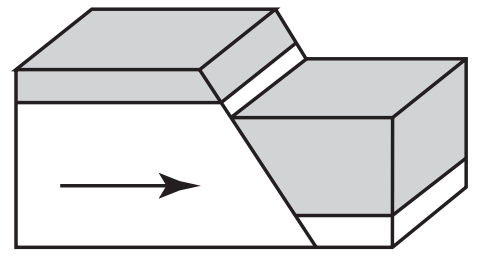

OPEN FAULT_Large drop in head across fault or, depending on permeability contrast, flow may change along fault

CLOSED FAULT_-If fault is less permeable than unit, there may be some springs or diffuse discharge upstream from fault; large drop in head across fault

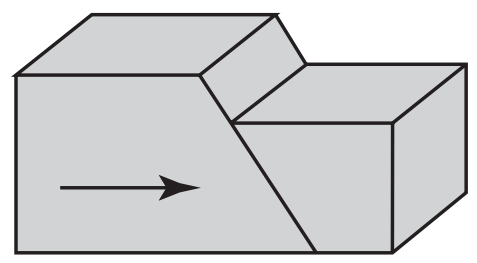

OPEN FAULT—Flow along fault or springs along fault line, possibly a large drop in head at and/or across fault

CLOSED FAULT—Springs or diffuse discharge upstream from fault

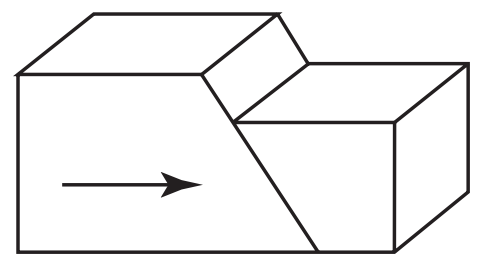

OPEN FAULT—If fault is more permeable than unit, possible flow along fault and/or springs along fault line; possible negligible effect

CLOSED FAULT_-If fault is less permeable than unit, there may be some springs or diffuse discharge upstream from fault; large drop in head across fault

\section{EXPLANATION}

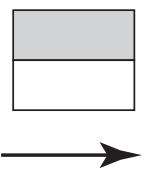

RELATIVELY LOW PERMEABILITY

RELATIVELY HIGH PERMEABILITY

\section{DIRECTION OF GROUND-WATER FLOW}

Figure 4. Potential effects of faults on ground-water flow for different types of aquifer and fault permeability. Modified from Faunt (1997, p. 32).

sediments are relatively short and occur as clusters of faults. Another pattern is that most faults in southern Nevada have relatively low slip rates and are generally older compared to faults along western Nevada and scattered locations in the north. Best and Hamblin (1978, p. 331) suggest that tectonic activity has moved progressively northward across the state and that fault activity in the southern part of the state (south of latitude $37^{\circ} \mathrm{N}$ ) has slowed since about $10 \mathrm{Ma}$.

The effect of faults on ground-water flow is difficult to determine without site-specific investigation. Faults may restrict ground-water flow in unconsolidated sediments and either restrict or enhance flow in consolidated rocks. The co-occurrence of faults and springs is one indication of the effect of faulting on ground-water flow (plate 1). Springs shown on plate 1 have flow of 200 to more than 1,000 gal/min (Harrill and others, 1988, plate 2). Most of the springs are in easterncentral Nevada in carbonate rocks, in unconsolidated sediments surrounded by carbonate rocks, or near the contact between consolidated rock/unconsolidated sediment where faults are common. Springs at this contact could be due to restricted ground-water flow caused by fault gouge or the juxtaposition of rocks with different hydraulic conductivity. Some springs in unconsolidated sediments occur along faults (White River Valley, HA 207; Amargosa Desert, HA 230), which is a good indication that these faults restrict ground-water flow. However, most faults that are distant from the contact between 
consolidated rock/unconsolidated sediment do not have springs, indicating ground-water flow is not sufficiently restricted to cause spring discharge.

The length of Quaternary-age faults within each hydrogeologic unit was divided by the area of the hydrogeologic unit (table 1) to evaluate relative amounts of faulting. Alluvial slopes and andesitic volcanic flows are the most faulted hydrogeologic units ( 0.2 and $0.19 \mathrm{mi}$ of fault per square mile, respectively). Basaltic volcanic flows have $0.17 \mathrm{mi}$ of fault per square mile, and intrusive and metamorphic rocks have $0.16 \mathrm{mi}$ of fault per square mile. Volcanic breccias, tuffs, and older volcanic rocks, carbonate rocks, clastic rocks, and Tertiary sediments have similar amounts of faulting $(0.12$ to $0.14 \mathrm{mi}$ of fault per square mile). Valley floors, rhyolite, playas, and stream channel deposits are the least faulted hydrogeologic units $(0.05$ to $0.10 \mathrm{mi}$ of fault per square mile). Units identified as water bodies have about 2.5 times more faults than the most faulted hydrogeologic unit (0.48 mi of fault per square mile).

\section{Hydrologic Landscape Regions}

The concept of regionalizing has been used in scientific and non-scientific disciplines as a way of generalizing a large amount of spatial information. A region is a large geographic area with fairly uniform values of the variables that are used to define the regions. A different value for one or more of these defining variables distinguishes regions from each other. For example, topography, climate, drainage, and other variables are used to delineate physiographic regions of the United States (Hunt, 1967). Although the Great Basin has similar topography and climate as other sections of the Basin and Range Physiographic Province, it is distinguished by its internal drainage. Hydrologic landscape regions (HLRs; Winter, 2001) are similar to physiographic regions. Hydrologic landscapes can be used as a conceptual tool to describe and evaluate hydrologic processes. For example, Winter (2000) used hydrologic landscapes to evaluate the vulnerability of wetlands to climatic change. Many variables control the flow of water, and this complexity needs to be considered when using hydrologic landscapes as a tool to evaluate hydrologic processes. For this study, discussion of HLRs emphasizes the susceptibility of ground water to contamination although it could be used to describe other hydrologic processes such as runoff.

\section{Delineation of Hydrologic Landscape Regions}

HLRs were delineated by gridding the state into $100-\mathrm{ft}$ (30-m) cells, estimating the value of five variables for each cell, and conducting cluster analysis to assign each cell to a region such that each region is fairly homogeneous and distinct from other regions (Davis, 2002). This cell size was used because that is the resolution of the National Elevation Dataset, which was used to estimate two variables, slope and aspect. The other three variables are mean annual precipitation, soil permeability, and hydrogeologic unit. These variables were chosen because state- wide maps exist and they were assumed to be related to aquifer susceptibility and contaminant transport. Hydrologic processes are controlled by many variables in addition to these five. Considering more variables would make HLRs too complex. Processing of the datasets was done using a geographic information system and the datasets are available at URL <http://water.usgs.gov/lookup/getspatial?nv_hlrnv_g>.

The five variables used to delineate HLRs are the same or similar to the seven variables that are used in DRASTIC (Aller and others, 1987), a commonly used method of evaluating aquifer susceptibility. Depth to water and recharge rates are not available statewide so they were not used to delineate HLRs. Precipitation was used instead of recharge because precipitation is directly related to recharge and is available statewide. Previous studies in Nevada have assumed that recharge is a fraction of certain precipitation intervals and is negligible in areas with less than 8 inches of precipitation (Maxey and Eakin, 1949; Nichols, 2000). If this assumption is correct, then about 33 percent of Nevada has a low susceptibility to contamination. DRASTIC uses an arbitrary weighting and ranking system to evaluate the relative susceptibility of an area to contamination. In contrast, HLRs only identify areas with similar hydrologic characteristics. Generalizations can be made about aquifer susceptibility based on the characteristics of each region and a conceptual understanding of ground-water flow.

Cluster analysis was done on categorical values for the five variables. Several iterations of categorizing were done to obtain a balance between showing differences in hydrologic characteristics while minimizing the number of regions. For the final iteration, the five variables were divided into either two or three descriptive categories with corresponding ranges in variable values. Nevada has 90 of the 108 unique combinations that were possible for the final iteration, which was chosen because it has a largely physical basis and the number of categories among variables is about the same.

Mean annual precipitation ranges from 4 to 52 in. in Nevada (Daly and others, 1994). Three iterations were done to categorize precipitation. The first two iterations categorized precipitation into equal intervals of 4-in. or 8-in. Categories for the third iteration were based on the areal distribution of precipitation. About 33 percent of Nevada has low ( $<8$ in.), 58 percent has moderate ( 8 to $<16$ in.), and 9 percent has high (>16 in.) precipitation. There was little difference in results of the cluster analysis between the 4-in. and 8-in. intervals. Most cells were assigned to regions with a median of 16 inches or less precipitation and a large variance. As a result, precipitation was not a distinguishing variable for most regions. The iteration using three categories based on areal distribution resulted in precipitation being a more distinguishing variable. Therefore, the three categories based on areal distribution were chosen for the final iteration.

Soil permeability was categorized using the five intervals of soil permeability that correspond to geomorphic features (table 3) and a simplified version with three categories: low $(<5 \mathrm{ft} / \mathrm{d})$, moderate (5 to $10 \mathrm{ft} / \mathrm{d})$, and high ( $>10 \mathrm{ft} / \mathrm{d})$. Similar to the results using large numbers of precipitation categories, the 


\section{Hydrogeology and Hydrologic Landscape Regions of Nevada}

five categories of soil permeability resulted in regions with a large variance in soil permeability. Therefore, the simplified version using three categories was chosen to better distinguish regions for the final iteration.

Topographic slope and aspect are important variables in snow accumulation, sublimation, and soil infiltration. Slope was divided into three categories: low ( $<3$ percent), moderate (3 to 25 percent), and high ( $>25$ percent). The 3 -percent slope break distinguishes valley floor from alluvial slopes and the 25 percent slope break is a critical condition for snow stability (Gray and Male, 1981, p. 501). Slopes greater than 25 percent are less likely to have significant snow accumulation due to avalanches. Aspect is the average compass direction that a cell faces and was divided into two categories based on the relative amount of solar radiation. Easterly, westerly and flat aspects receive similar solar radiation, and southerly aspects receive the most radiation. Northerly aspects receive considerably less radiation than non-northerly aspects (Gray and Male, 1981, p. 365). As a result, snow is more likely to infiltrate and less likely to sublimate and runoff from northerly slopes compared to non-northerly slopes. The range in northerly aspect that is hydrologically significant is unknown, so a wide range was used. Northerly slopes are greater than 3 percent and have an aspect of 300 to 60 degrees; non-northerly slopes are less than 3 -percent or greater than 3-percent slope and have an aspect of 299 to 61 degrees.

There are few data on vertical hydraulic conductivity, which can be orders of magnitude less than the horizontal hydraulic conductivity. Therefore, horizontal hydraulic conductivity was used to categorize hydrogeologic units because it affects the transport rate after a contaminant has entered the aquifer. A large or small area of an aquifer could be susceptible to contamination depending on horizontal hydraulic conductivity, attenuation, and other factors. A mean of the range of less than or greater than $40 \mathrm{ft} / \mathrm{d}$ for horizontal hydraulic conductivity was used to categorize hydrogeologic units. This value divides hydrogeologic units into categories of low or high horizontal hydraulic conductivity fairly well. No other meaningful break in horizontal hydraulic conductivity is apparent (fig. 2). Carbonates, basalt, and unconsolidated sediments except for playas comprise hydrogeologic units with high horizontal hydraulic conductivity. Playas, rhyolite, andesite, breccia/tuff, intrusives/ metamorphics, sandstone, siltstone, and tertiary sedimentary rocks comprise hydrogeologic units with low horizontal hydraulic conductivity. Rhyolite and volcanic breccias, tuffs and volcanic rocks older than Tertiary age seem to have high horizontal hydraulic conductivity (table 2 ). However, this is due to a few anomalous hydraulic conductivity values reported for these units (appendix 1). These hydrogeologic units generally are not productive aquifers and most reported values are less than $40 \mathrm{ft} / \mathrm{d}$.

Cluster analysis was done using two techniques on truly categorical values, such as high and low, and on numerical values, such as 1 and 2, assigned to each category. Numerical values for the categories were not significantly correlated, so autocorrelation among variables was not a problem.
Partitioning-around-medoids (PAM) and agglomerativehierarchical $(\mathrm{AH})$ cluster analysis on the standardized values were solved using S-Plus 6.1 (Mathsoft, 2001). The number of clusters was increased until each region had only one category of hydrogeologic unit. This criterion for the minimum number of clusters was used because it has a physical basis as opposed to statistical criteria that can be used to estimate the optimal number of clusters. PAM using numerical values for categories resulted in a minimum of 16 regions. Values of other variables in each region have little variance and, except for 2 regions, have symmetrical distributions (fig 5). PAM using truly categorical values and AH using both categorical types resulted in 21 or more regions, and other variables had large variances. Therefore, PAM using numerical values was chosen for the final cluster analysis because this technique was most efficient at producing the fewest regions that are homogeneous and distinct from each other. The resulting map was nominally filtered-a raster- processing technique that removed clusters of fewer than 40 cells that are of a different HLR than their surroundings (plate 4; table 3).

Differences in all five variables distinguish the HLRs. Most of Nevada has moderate precipitation (58 percent), low soil permeability (50.1 percent), moderate slope (58.1 percent), non-northerly aspect (88.7 percent), and high horizontal hydraulic conductivity (59.8 percent; table 4 ). Without considering combinations of these variables, these characteristics indicate that most of Nevada could have a high susceptibility to contamination. For example, if recharge occurs where precipitation is more than 8 inches (Maxey and Eakin, 1949; Nichols, 2000), then most of Nevada is susceptible regardless of other variables. However, susceptibility is a function of many variables. Even if variables indicate a low susceptibility, aquifers could be vulnerable due to rapid development in Nevada. Irrigation, urban runoff, septic tanks, and other landuse practices could flush contaminants into ground water.

Regions with moderate to high precipitation, soil permeability, and horizontal hydraulic conductivity and low to moderate slope could be more susceptible to contamination than other regions. These characteristics describe HLRs 9, 14, and 15, which comprise 27.1 percent of Nevada. HLRs 9, 14, and 15 represent alluvial slopes and valley floors and occur in most basins of eastern and central Nevada (plate 4). Aspect could be an important variable affecting susceptibility in HLR 14 because Indian Springs Valley (HA 161) and Three Lakes Valley (HA 211) have a large amount of slopes with a northerly aspect. Aspect may not be an important variable for other HLRs because of the scattered distribution of northerly slopes.

Almost 90 percent of Nevada's population lives on hydrogeologic units with high horizontal hydraulic conductivity. HLR 9 could be more susceptible to contamination than other regions and has 38 percent of Nevada's population, indicating it also is vulnerable. Except for its low precipitation, HLR 10 has similar characteristics to HLR 9 and 25.9 percent of the Nevada's population, suggesting it also could be vulnerable. HLR 9 represents the alluvial slopes and valley floors of western Las Vegas and Spanish Springs, alluvial slopes and fluvial 


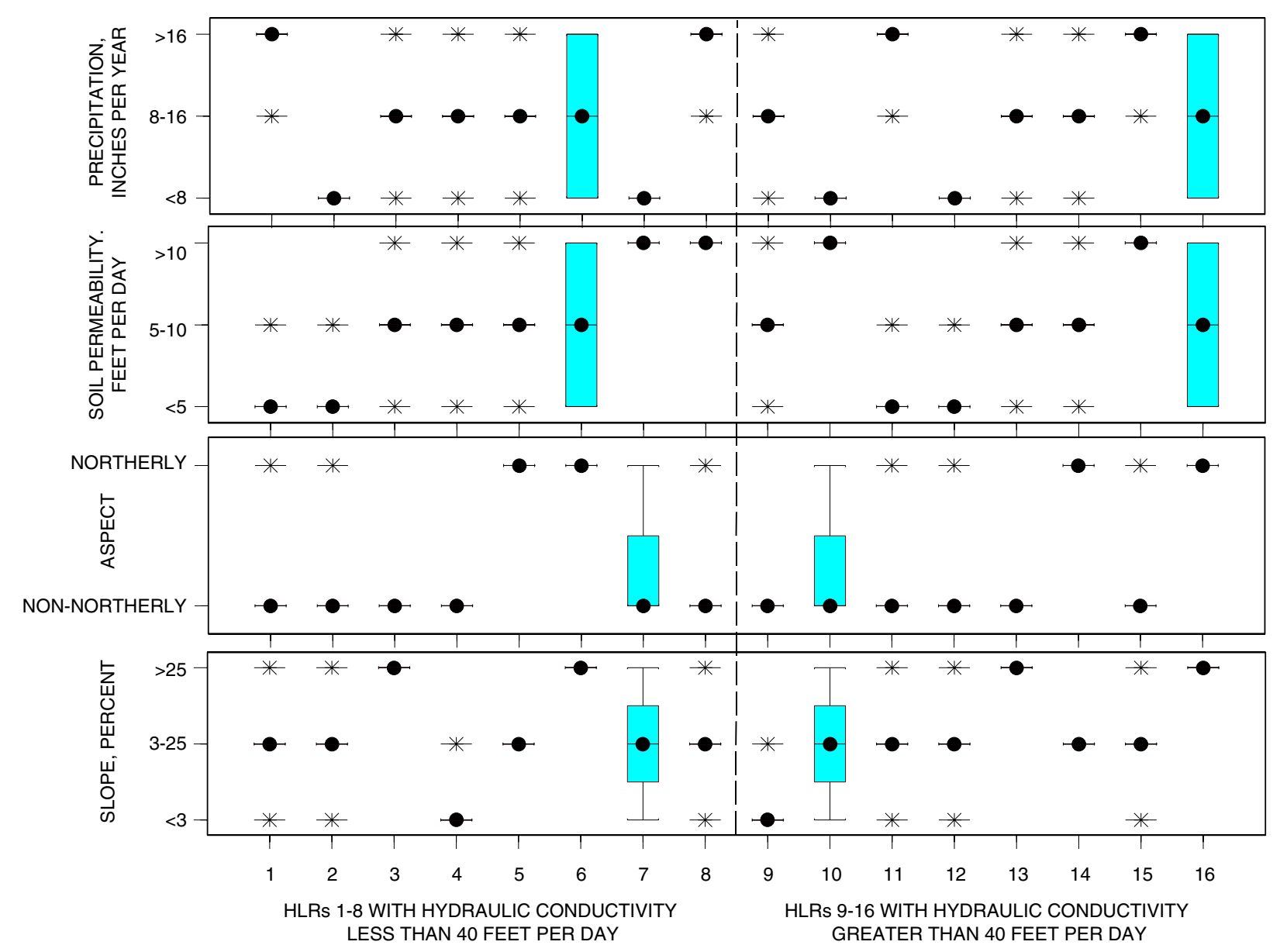

Figure 5. Ranges in mean annual precipitation, soil permeability, slope, and aspect for hydrologic landscape regions with low and high horizontal hydraulic conductivity.

deposits of western Reno, and valley floors where virtually all the population is located in Carson City, Minden, and Gardnerville (Fig. 6a). HLR 10 represents alluvial slopes and valley floors of southern Las Vegas (Fig. 6b). These areas could be most vulnerable due to their hydrologic characteristics and urban land-use practices that use water and chemicals. Development on alluvial slopes could be of particular concern because contaminants could reach the deep aquifer that is used for public supply by most cities.

\section{Use of Hydrologic Landscape Regions}

Hydrologic information representing much of the State can be obtained by conducting studies in strategic locations so that the results would have high transfer value. For example, 5 of the 16 HLRs comprise more than 60 percent of the State. A limited number of detailed studies in these HLRs could greatly improve the understanding of hydrologic processes throughout much of Nevada.
This approach of using the HLRs as a framework to represent various hydrologic settings in Nevada is being used as part of a statewide evaluation of ground-water susceptibility and vulnerability. Previous studies (Eckhardt and Stackelberg, 1995; Squillace and others, 1999) found that population density is correlated with the occurrence of anthropogenic contaminants. This correlation and the HLRs were used to design a stratified sampling strategy that represents both natural and anthropogenic factors affecting ground water quality. Within each HLR, samples are being collected in low to high population-density areas. Samples are being analyzed for dissolved solids and nutrients including nitrate, which is one of the most commonly occurring anthropogenic contaminants. Samples also are being dated using chlorofluorocarbons to determine where ground water has recharged during the past 50 years (Plummer and Friedman, 1999). The occurrence of young ground water indicates that the aquifer is susceptible to contamination. 
Table 4. Characteristics, distribution, area, and population of hydrologic landscape regions (HLR)

[Abbreviation: HA, hydrographic area. Area is rounded to 10 square miles and percent is rounded to one decimal place.]

\begin{tabular}{|c|c|c|c|c|c|c|c|}
\hline HLR & $\begin{array}{l}\text { Precipitation, } \\
\text { inches/year }\end{array}$ & $\begin{array}{l}\text { Soil } \\
\text { permeability, } \\
\text { feet/day }\end{array}$ & $\begin{array}{l}\text { Slope, } \\
\text { percent }\end{array}$ & Aspect & Predominant distribution & $\begin{array}{l}\text { Area, square miles } \\
\text { (percent of total) }\end{array}$ & $\begin{array}{l}2000 \text { population } \\
\text { (percent of total) }\end{array}$ \\
\hline \multicolumn{8}{|c|}{ Low horizontal hydraulic conductivity ( $<40$ feet/day) } \\
\hline 1 & $>16$ & $<5$ & 3 to 25 & Non-northerly & Owyhee Upland, Modoc Plateau, most ranges throughout Nevada & $14,390(13.1)$ & $60,616(3.0)$ \\
\hline 2 & $<8$ & $<5$ & 3 to 25 & Non-northerly & $\begin{array}{l}\text { Playas in Black Rock Desert (HA 28) and Smoke Creek Desert } \\
\text { (HA 21), Carson Sink, and southwestern Nevada }\end{array}$ & $8,110(7.4)$ & $30,006(1.5)$ \\
\hline 3 & 8 to 16 & 5 to 10 & $>25$ & Non-northerly & Ranges in central and southeastern Nevada & $6,750(6.1)$ & $16,185(0.8)$ \\
\hline 4 & 8 to 16 & 5 to 10 & $<3$ & Non-northerly & Playas in Desert Valley (HA 31) and central eastern Nevada & $5,700(5.2)$ & $29,984(1.5)$ \\
\hline 5 & 8 to 16 & 5 to 10 & 3 to 25 & Northerly & Small, scattered areas in consolidated rock throughout Nevada & $2,840(2.6)$ & $15,271(0.8)$ \\
\hline 6 & 8 to 16 & 5 to 10 & $>25$ & Northerly & Small, scattered areas in consolidated rock throughout Nevada & $2,660(2.4)$ & $7,863(0.4)$ \\
\hline 7 & $<8$ & $>10$ & 3 to 25 & Non-northerly & Playas and consolidated rock in western to southern Nevada & $2,570(2.3)$ & $51,234(2.6)$ \\
\hline 8 & $>16$ & $>10$ & 3 to 25 & Non-northerly & Fortymile Canyon (HA 227B) and ranges in northwestern Nevada & $1,100(1.0)$ & $15,481(0.8)$ \\
\hline \multicolumn{8}{|c|}{ High horizontal hydraulic conductivity ( $>40$ feet/day) } \\
\hline 9 & 8 to 16 & 5 to 10 & $<3$ & Non-northerly & Valley floors in east central and north central Nevada & $24,390(22.2)$ & $759,691(38.0)$ \\
\hline 10 & $<8$ & $>10$ & 3 to 25 & Non-northerly & Alluvial slopes from western to southern Nevada & $13,330(12.1)$ & $517,549(25.9)$ \\
\hline 11 & $>16$ & $<5$ & 3 to 25 & Non-northerly & Ranges in central eastern and western Nevada & $10,260(9.3)$ & $58,555(2.9)$ \\
\hline 12 & $<8$ & $<5$ & 3 to 25 & Non-northerly & Alluvial slopes in southwestern and southern Nevada & $6,750(6.1)$ & $388,411(19.5)$ \\
\hline 13 & 8 to 16 & 5 to 10 & $>25$ & Non-northerly & Ranges in eastern and southern Nevada & $4,200(3.8)$ & $10,010(0.5)$ \\
\hline 14 & 8 to 16 & 5 to 10 & 3 to 25 & Northerly & $\begin{array}{l}\text { Indian Springs Valley (HA 161), Three Lakes Valley (HA 211), } \\
\text { and small, scattered areas in consolidated rock throughout } \\
\text { Nevada }\end{array}$ & $3,210(2.9)$ & $24,251(1.2)$ \\
\hline 15 & $>16$ & $>10$ & 3 to 25 & Non-northerly & Alluvial slopes in eastern and southern Nevada & $2,160(2.0)$ & $8,116(0.4)$ \\
\hline 16 & 8 to 16 & 5 to 10 & $>25$ & Northerly & $\begin{array}{l}\text { Small, scattered areas in consolidated rock in eastern and } \\
\text { southern Nevada }\end{array}$ & $1,440(1.3)$ & $3,419(0.2)$ \\
\hline
\end{tabular}


$\boldsymbol{A}$

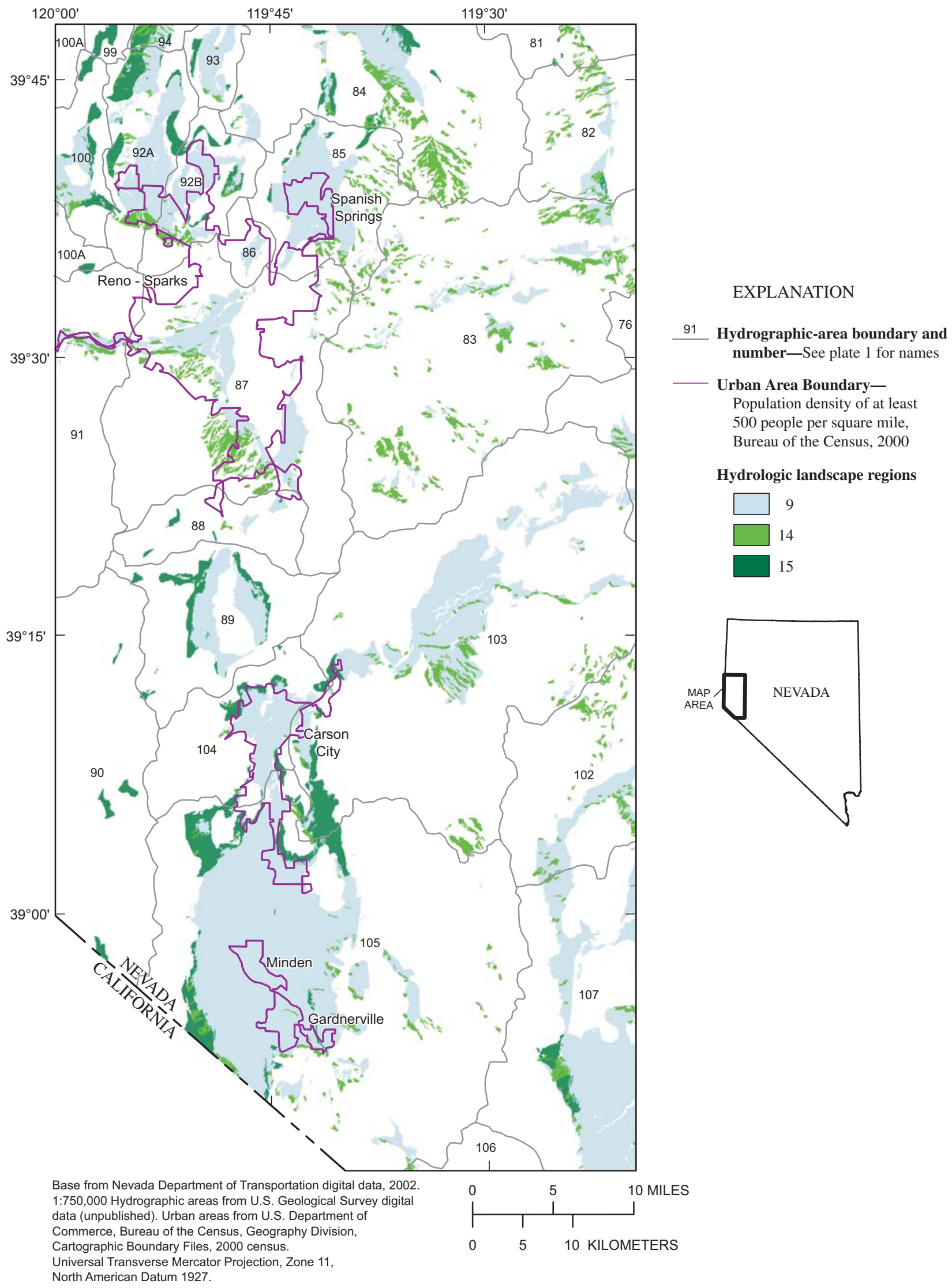

Figure 6. Hydrologic landscape regions $9,10,14$, and 15 in the most urbanized areas of Nevada. $A$, Reno-Sparks, Carson City, Minden and Gardnerville areas. $B$, Las Vegas, Boulder City, and Pahrump, Nevada. 
B

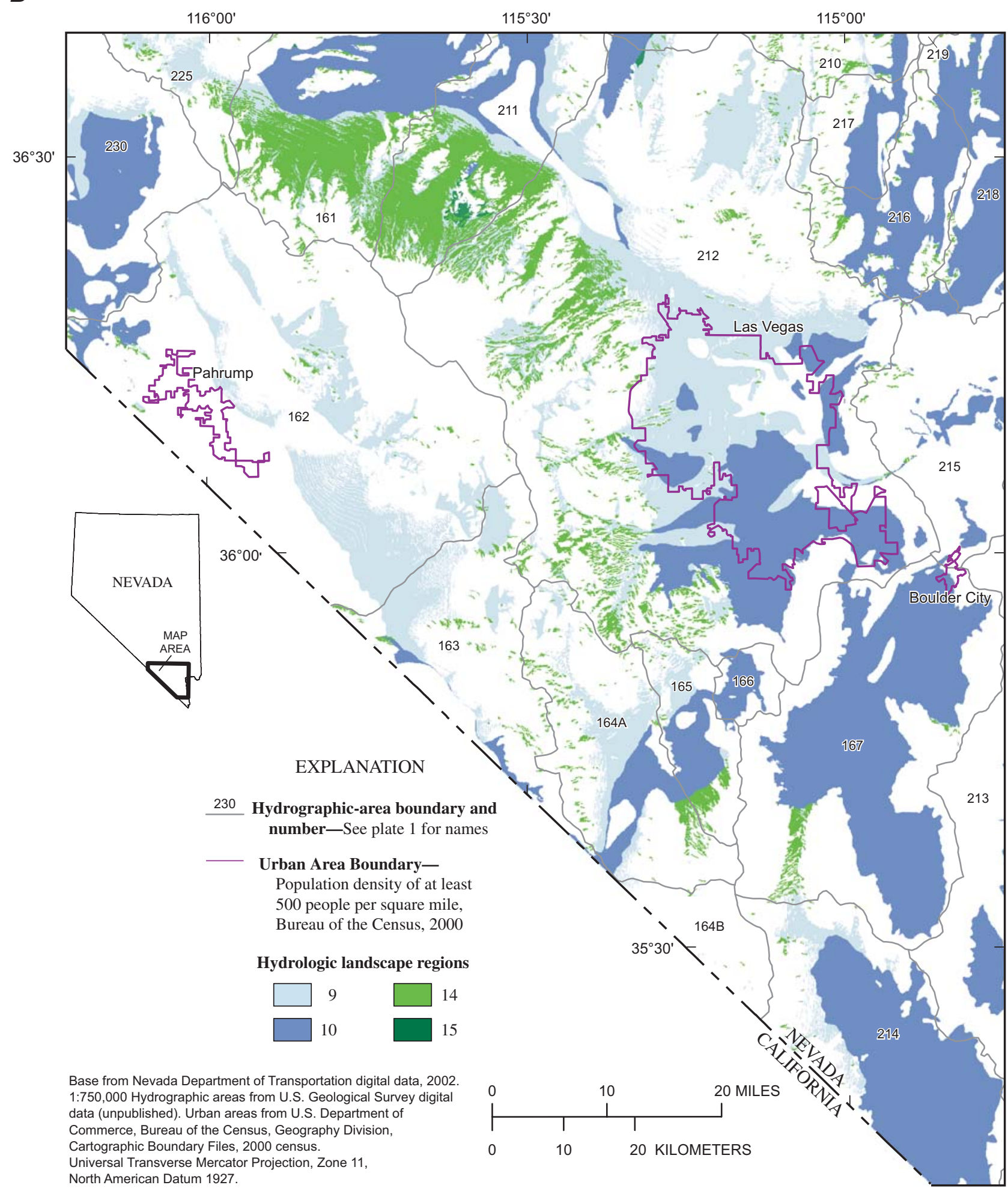

Figure 6. -- Continued. 
An example of a sampling design using HLRs is shown in table 5. A certain number of samples are collected in each HLR that represents a range in population density. The number of samples may not be equal among HLRs for various reasons. For example, more samples may be collected in the most densely populated areas of an HLR, more samples may be collected in HLRs with the largest total population, and no samples may be collected in HLRs that are a small percentage of the total area and population.

Table 5. Example of a sampling strategy using hydrologic landscape regions

[Abbreviation: HLR, hydrologic landscape region.]

\begin{tabular}{|c|c|c|c|c|}
\hline \multirow{2}{*}{ HLR } & \multicolumn{4}{|c|}{ Range in population density } \\
\hline & $\begin{array}{c}\text { 1st } \\
\text { quartile }\end{array}$ & $\begin{array}{c}\text { 2nd } \\
\text { quartile }\end{array}$ & $\begin{array}{c}\text { 3rd } \\
\text { quartile }\end{array}$ & $\begin{array}{c}\text { 4th } \\
\text { quartile }\end{array}$ \\
\hline 1 & 2 & 3 & 4 & 5 \\
\hline 2 & 2 & 3 & 4 & 5 \\
\hline 3 & 2 & 2 & 2 & 2 \\
\hline 4 & 2 & 2 & 3 & 3 \\
\hline 5 & 2 & 2 & 2 & 2 \\
\hline 6 & 2 & 2 & 2 & 2 \\
\hline 7 & 2 & 2 & 2 & 2 \\
\hline 8 & 0 & 0 & 0 & 0 \\
\hline 9 & 4 & 5 & 5 & 6 \\
\hline 10 & 3 & 4 & 4 & 5 \\
\hline 11 & 3 & 4 & 4 & 5 \\
\hline 12 & 3 & 3 & 3 & 3 \\
\hline 13 & 2 & 2 & 2 & 2 \\
\hline 14 & 2 & 2 & 2 & 2 \\
\hline 15 & 0 & 0 & 0 & 0 \\
\hline 16 & 0 & 0 & 0 & 0 \\
\hline
\end{tabular}

\section{Summary}

In 1999, the U.S. Environmental Protection Agency initiated a rule to protect ground water in areas other than sourcewater protection areas. These OSGWAs are aquifers that are not currently but could eventually be used as a source of drinking water. NDEP will evaluate site-specific information and determine if an aquifer associated with a permit application is susceptible to contamination. A basic part of evaluating OSGWAs is characterizing the hydrogeology of aquifer systems including the lithology, hydrologic properties, soil permeability, and faulting, which partly control the susceptibility of ground water to contamination. Detailed studies that evaluate ground-water susceptibility are not practical in a largely unpopulated State like Nevada. However, existing and new information could be extrapolated to other areas of the State if there is an objective framework to transfer the information. The concept of hydrologic landscape regions, which identify areas with similar hydrologic characteristics, provides this framework.
Hydrogeologic units are geologic formations with similar lithology and assumed to have similar hydrologic properties. The geologic map of Nevada is the primary source of lithology used to delineate hydrogeologic units. Because the hydrologic properties of consolidated rocks and unconsolidated sediments are quite different, they comprise the two major hydrogeologic units. Consolidated rocks are exposed over 56,000 mi2 (51 percent) of Nevada and unconsolidated sediments are exposed over $54,000 \mathrm{mi} 2$ (49 percent) of the State. These two major hydrogeologic units were further subdivided into more detailed hydrogeologic units based on lithology, horizontal hydraulic conductivity, slope, and mapped stream channels.

Consolidated rocks were subdivided into eight hydrogeologic units. In order of decreasing area covering Nevada, the eight consolidated-rock hydrogeologic units consist of Quaternary to Tertiary age volcanic flows of (1) basaltic, (2) rhyolitic, and (3) andesitic composition; (4) volcanic breccias, tuffs, and volcanic rocks older than Tertiary age; (5) carbonate rocks; (6) Tertiary-age consolidated and semiconsolidated tuffaceous rocks and sediments, (7) clastic rocks consisting of sandstone and siltstone; and (8) intrusive and metamorphic rocks.

Unconsolidated sediments were subdivided into four hydrogeologic units. Alluvial slopes were defined as unconsolidated sediments with a topographic slope greater than 3 percent. Alluvial slopes typically are recharge areas with downward ground-water flow and high gradients. Valley floor deposits have a topographic slope of less than 3 percent. Ground-water flow beneath valley floors generally is parallel to land surface or upward, vertical flow is restricted by layering, and gradients are low. Fluvial deposits could be areas of preferential flow and were mapped as a separate unit using Landsat imagery. Playas have low hydraulic conductivities and were mapped by Stewart and Carlson (1978a).

Soil permeability was grouped into five descriptive categories ranging from very high to very low, which generally correspond to mapped geomorphic features such as playas, alluvial slopes, flood plains, and stream channels. In general, soil permeability is low to moderate in northern, northeastern, and eastern Nevada and high to very high in western, southwestern, and southern Nevada. Within a particular basin, soil permeability decreases down slope from the bedrock contact. The type of parent rock, climate, and streamflow velocities are factors that likely cause these spatial patterns. Soil thickness is significantly correlated with slope and decreases from about $60 \mathrm{in}$. on flat slopes to about $30 \mathrm{in.}$ on 40-percent slopes.

Faults in unconsolidated sediments usually are barriers to ground-water flow. However, in the unsaturated zone, finegrained fault gouge may act as a capillary conduit to the water table. In consolidated rocks, permeability and ground-water flow is reduced in directions normal to the fault zone and increased in directions parallel to the fault zone. During geologic time, fractures in consolidated rocks may become cemented and sealed due to precipitation of carbonate minerals, reducing the permeability. However, continued movement along the fault may form new fractures so that a fault may cycle 
between a zone of preferred flow and a flow barrier. The effect of faults on ground-water flow is difficult to determine without site-specific investigation.

HLRs were delineated by gridding the State into 100-ft (30-m) cells, estimating the value of five variables for each cell, and conducting cluster analysis to assign each cell to a region such that each region is fairly homogeneous and distinct from other regions. The five variables include mean annual precipitation, soil permeability, slope, aspect, and hydrogeologic unit. The number of clusters was increased until each region had only one category of hydrogeologic unit, which resulted in 16 regions. Five of the 16 HLRs comprise more than 60 percent of the State. A limited number of detailed studies in these HLRs could greatly improve the understanding of hydrologic processes throughout much of Nevada.

Most (59.8 percent) of Nevada is comprised of HLRs with high horizontal hydraulic conductivity. Regions with moderate to high precipitation, moderate to high soil permeability, low to moderate slope, and high hydraulic conductivity could have greater recharge rates and be more susceptible to contamination relative to other regions. These characteristics describe HLRs 9, 14 and 15, which comprises 27.1 percent of Nevada and represent alluvial slopes and valley floors in most basins of eastern and central Nevada. Aspect could be an important variable affecting susceptibility in Indian Springs Valley (HA 161) and Three Lakes Valley (HA 211) because they have a large amount of slopes with a northerly aspect. Aspect may not be an important variable for other HLRs because of the scattered distribution of northerly slopes.

Almost 90 percent of Nevada's population lives on hydrogeologic units with high horizontal hydraulic conductivity. HLR 9 could be more susceptible than other regions and has 38 percent of Nevada's population, indicating it also is vulnerable to contamination. HLR 9 represents the alluvial slope and valley floor of western Las Vegas and Spanish Springs, alluvial slope and fluvial deposits of western Reno, and valley floor of Carson City, Minden, and Gardnerville where virtually all the population is located. These areas could be most vulnerable due to their hydrologic characteristics and contaminants associated with urban land-use practices.

\section{References Cited}

Abrahams, A.D., and Parsons, A.J., eds., 1994, Geomorphology of desert environments, Chapman \& Hall, London, U.K., $674 \mathrm{p}$.

Aller, L., Bennet, T., Lehr, J.H., and Petty, R.J., 1987, DRASTIC: a standardized system for evaluating groundwater pollution potential using hydrogeologic settings, U.S. Environmental Protection Agency Report 600/2-85/018.
Anderson, R.E., Zoback, M.L., and Thompson, G.A., 1983, Implications of selected subsurface data on the structural form and evolution of some basins in the northern Basin and Range province, Nevada and Utah: Geological Society of America Bulletin, v. 94, p. 1055-1072.

Antonellini, Marco, Aydin, Atilla, and Orr, Lynn, 1999, Outcrop-aided characterization of a faulted hydrocarbon reservoir: Arroyo Grande Oil Field, California, USA, in Haneberg, W.C., Mozley, P.S., Moore, J.C., and Goodwin, L.B., eds., Faults and subsurface fluid flow in the shallow crust, Geophysical Monograph 113, American Geophysical Union, Washington, D.C., 222 p.

Aquifer Science Inc., 2001, Wellhead protection program for Cottonwood Mobile Home Park water system: Aquifer Science Inc, Salt Lake City, Utah, 8 numbered sections, 1 glossary.

Bedinger, M.S., Langer, W.H., and Reed, J.E., 1986, Synthesis of hydraulic properties of rocks with reference to the Basin and Range Province, southwestern United States, in Selected papers in the hydrologic sciences, U.S. Geological Survey Water-Supply Paper 2310, p. 35-41.

Bedsun, D.A., 1980, Geological and hydrological profiles in Missile-X valleys: Defense Nuclear Agency, Air Force Weapons Laboratory, Kirtland Air Force Base, New Mexico, $69 \mathrm{p}$.

Belcher, W.R., Elliot, P.E., and Geldon, A.L., 2001, Hydraulicproperty estimates for use with a transient ground-water flow model of the Death Valley regional ground-water flow system, Nevada and California: U.S. Geological Survey Water-Resources Investigations Report 01-4210, 25 p.

Berger, D.L., 1995, Ground-water conditions and effects of mine dewatering in Desert Valley, Humboldt and Pershing Counties, northwestern Nevada, 1962-91: U.S. Geological Survey Water-Resources Investigations Report 95-4119, $79 \mathrm{p}$.

Berger, D.L., Ross, W.C., Thodal, C.E., and Robledo, A.R., 1997, Hydrogeology and simulated effects of urban development on water resources of Spanish Springs Valley, Washoe County, west-central Nevada: U.S. Geological Survey Water-Resources Investigations Report 96-4297, 80 p.

Berger, D.L., 2000, Water budgets for Pine Valley, Carico Lake Valley, and Upper Reese River Valley Hydrographic Areas, middle Humboldt River basin, north-central Nevada-Methods for estimation and results: U.S. Geological Survey Water-Resources Investigations Report 99-4272, 40 p.

Best, M.G., and Hamblin, W.K., 1978, Origin of the northern Basin and Range Province: Implications from the geology of its eastern boundary, in Smith R.B., and Eaton G.P. eds., Cenozoic tectonics and regional geophysics of the western Cordillera, Geological Society of America, Memoir 152, $388 \mathrm{p}$.

Bredehoeft, J.D., 1963, Hydrogeology of the lower Humboldt River Basin, Nevada: Nevada Department of Conservation and Natural Resources, Bulletin 21, 50 p. 
Buol, S.W., Hole, F.D., and McCracken, R.J., 1973, Soil genesis and classification: The Iowa State University Press, Ames, Iowa, $360 \mathrm{p}$.

Caine, J.S., and Forster, C.B., 1999, Fault zone architecture and fluid flow-Insights from field data and numerical modeling, in Haneberg, W.C., Mozley, P.S., Moore, J.C., and Goodwin, L.B., eds., 199, Faults and subsurface fluid flow in the shallow crust: American Geophysical Union Monograph, v. 113, p. 101-127.

Camp Dresser \& McKee, Inc., 1996, Final draft groundwater flow and contaminant transport technical memoranda for agency review, v. 2, appendices A-F.

Campana, M.E., 1987, Hydraulic effects of surface discharge on the shallow groundwater system-Dixie Valley Geothermal Project: Desert Research Institute, Water Resources Center, Reno, Nevada, 26 p.

Candland, D.M., 1984, Soil survey of Douglas County area, Nevada: United States Department of Agriculture, Soil Conservation Service, $575 \mathrm{p}$.

Cardinalli, J.L., Roach, L.M., Rush, F.E., and Vasey, B.J., comps., 1968, State of Nevada hydrographic areas: Nevada Division of Water Resources Bulletin 33, 162 p.

CDM Engineers and Consultants, Inc., 1997, Rocketdyne former Nevada Field Lab, Area D groundwater remediation system as-built/startup report, v. 1: prepared for Boeing North America, Inc., Canoga Park, California, 5 numbered sections, 3 appendices.

CH2MHill, 1986, First quarter report Steamboat Springs environmental baseline study: prepared for Phillips Petroleum Company, Geothermal branch, 8 numbered sections.

Cohen, Philip, 1963, Water Resources of the Humboldt River Valley near Winnemucca, Nevada: U.S. Geological Survey Water-Supply Paper 1795, 143 p.

Consulting Services Associates, Inc., 1997, Asamera Mineral (U.S.) Inc. water rights report: Consulting Services Associates, Inc., Reno, Nevada, 10 p.

D'Agnese, F.A., Faunt, C.C., Turner, A.K., and Hill, M.C., 1997, Hydrogeologic evaluation and numerical simulation of the Death Valley regional ground-water flow system, Nevada and California: U.S. Geological Survey Water-Resources Investigations Report 96-4300, $124 \mathrm{p}$.

D'Agnese, F.A., O'Brien, G.M., Faunt, C.C., Belcher, W.R., and San Juan, Carma, 2002, A three-dimensional numerical mode of predevelopment conditions in the Death Valley regional ground-water flow system, Nevada and California: U.S. Geological Survey Water-Resources Investigations Report 02-4102, 114 p.

Daly, Christopher, Neilson, R.P., and Phillips, D.L., 1994, A statistical-topographic model for mapping climatological precipitation over mountainous terrain: Journal of Applied Meteorology, v. 33, no. 2, p. 140-158.

Davis, G.H., 1988, Western alluvial valleys and the High Plains, in Back, W., Rosenshein, J.S., and Seaber, P.R., eds., Hydrogeology, v. O-2, Geology of North America, 524 p.
Davis, J.C., 2002, Statistics and data analysis in geology: John Wiley and Sons, New York, 638 p.

Davis, S.N., and DeWiest, R.J.M., 1966, Hydrogeology: John Wiley \& Sons, Inc, New York, 463 p.

Denny, C.S., 1965, Alluvial fans in the Death Valley Region: U.S. Geological Survey Professional Paper 466, 62 p.

Eakin, T.E., Price, Don, and Harrill, J.R., 1976, Summary appraisals of the Nation's ground-water resources-Great Basin Region: U.S. Geological Survey Professional Paper 813-G, $37 \mathrm{p}$.

Earth Technology Corporation, 1993, Corrective action plan-Smitten Oil and Tire Company, Fallon, Nevada: prepared for Smitten Oil and Tire Company, Fallon, Nevada, 10 numbered sections.

Eckhardt, D.A.V., and Stackelberg, P.E., 1995, Relation of ground-water quality to land use on Long Island, New York: Ground Water, v. 33, no. 6, p. 1019-1033.

Errol L. Montgomery and Associates, Inc., 1988, Data compilation and preliminary assessment of hydrogeologic conditions, Sleeper Mine area: Nevada Gold Mining, Inc., Humboldt County, Nevada, $48 \mathrm{p}$.

Faunt, C.C., 1997, Effect of faulting on ground-water movement in the Death Valley region, Nevada and California: U.S. Geological Survey Water-Resources Investigations Report 95-4132, $42 \mathrm{p}$.

Focazio, M.J., Reilly, T.E., Rupert, M.G., and Helsel, D.R., 2002, Assessing ground-water vulnerability to contamination: Providing scientifically defensible information for decision makers: U.S. Geological Survey Circular 1224, 33 p.

Freeze, R.A., and Cherry, J.A., 1979, Groundwater: Englewood Cliffs, New Jersey, Prentice-Hall, 604 p.

French, R.H., 1987, Developments in water science, 31, Hydraulic process on alluvial fans: Elsevier, New York, $244 \mathrm{p}$.

Geomega, Inc., 1997, Groundwater flow and transport subregional model Giroux Wash tailings impoundment: prepared for BHP Copper-Robinson Operations, Geomega, Inc., Boulder, Colorado, $56 \mathrm{p}$.

Geomega, Inc., 1998a, Groundwater flow modeling report for the South Pipeline project: prepared for Cortez Gold Mines, Beowawe, Nevada, 9 number sections, 8 appendices.

Geomega, Inc., 1998b, An analysis of reactive solute transport in groundwater underlying the Robinson mining district, New Ruth, Nevada: prepared for BHP Copper Operations, Ruth, Nevada, 9 numbered sections, 3 appendices.

Goodwin, L.B., Mozley, P.S., Moore, J.C., and Haneberg, W.C., 1999, Introduction, in Haneberg, W.C., Mozley, P.S., Moore, J.C., and Goodwin, L.B., eds., Faults and subsurface fluid flow in the shallow crust: Geophysical Monograph 113, American Geophysical Union, Washington, D.C., 222 p.

Gray, D.M., and Male, D.H., eds., 1981, Handbook of snow: principles, processes, management, and use: Pergamon Press Inc., New York, 776 p. 
Groundwater Resources Consultants, Inc., 1994, Site characterization of Area D of the Rockwell International Corporation former Nevada Field Laboratory, Washoe County, Nevada, v. 1, $31 \mathrm{p}$.

GTE California, Inc., 1998, Site characterization reports GTE Topaz Autovon facility, Topaz Mountain, Nevada: prepared for Bureau of Corrective Actions, Division of Environmental Protection, Carson City, Nevada; 47 p.

Handman E.H., and Kilroy, K.C., 1997, Ground-water resources of northern Big Smoky Valley, Lander and Nye Counties, central Nevada: U.S. Geological Survey WaterResources Investigations Report 96-4311, 97 p.

Handman, E.H., Londquist, C.J., and Maurer, D.K., 1990, Ground-water resources of Honey Lake Valley, Lassen County, California, and Washoe County, Nevada: U.S. Geological Survey Water-Resources Investigations Report 90-4050, 112 p.

Harrill, J.R., 1986, Ground-water storage and depletion in Pahrump Valley, Nevada-California, 1962-75: U.S. Geological Survey Water-Supply Paper 2279, 53 p.

Harrill, J.R., Gates, J.S., and Thomas, J.M., 1988, Major ground-water flow systems in the Great Basin region of Nevada, Utah, and adjacent states: Hydrologic Investigations Atlas HA-694-C, 2 map sheets.

Harrill, J.R., and Preissler, A.M., 1994, Ground-water flow and simulated effects of development in Stagecoach Valley, a small, partly drained basin in Lyon and Storey Counties, Western Nevada: U.S. Geological Survey Professional Paper 1409-H, 74 p.

Harrill, J.R., and Prudic, D.E., 1998, Aquifer systems in the Great Basin region of Nevada, Utah, and adjacent states-Summary report: U.S. Geological Survey Professional Paper 1409-A, 66 p.

Heynekamp, M.R., Goodwin, L.B., Mozley, P.S., and Haneberg, W.C., 1999, Controls on fault-zone architecture in poorly lithified sediments, Rio Grande Rift, New Mexico: implications for fault-zone permeability and fluid flow, in Haneberg, W.C., Mozley, P.S., Moore, J.C., and Goodwin, L.B., eds., Faults and subsurface fluid flow in the shallow crust, Geophysical Monograph 113, American Geophysical Union, Washington, D.C., 222 p.

Hunt, C.B., 1967, Physiography of the United States: W.H. Freeman and Co., San Francisco, 480 p.

Hydrologic Consultants, Inc., 2000, 1999 update of numerical ground-water flow modeling for Newmont Mining Corporation's Lone Tree Mine Humboldt County, Nevada: prepared for Newmont Mining Corporation, HCI-834, Lakewood, Colorado, 39 p.

JBR Consultants Group, 1989, Technical report in support of an application for a Class V injection well Cyanco Winnemucca plant: prepared for Cyanco, Salt Lake City, Utah, 33 p.

Johnson, A.I., Moston, R.P., and Morris, D.A., 1968, Physical and hydrologic properties of water-bearing deposits in subsiding areas in central California: U.S. Geological Survey Professional Paper 497-A, 71 p.
Johnson, M.G., 1977, Geologic and mineral deposits of Pershing County, Nevada: Nevada Bureau of Mines and Geology, Bulletin 89, 115 p.

Knight Piesold and Co., 2002a, Elko County school district, Spring Creek junior/senior high school campus, wellhead protection program, final report: Elko County School District and Knight Piesold and Co., Elko, Nevada, 23 p.

Knight Piesold and Co., 2002b, City of Wells, wellhead protection program: Knight Piesold and Co., Elko, Nevada, 8 numbered sections, 3 appendices.

Lander County and Nevada Rural Water Association, 2001, Lander County Sewer and Water District \#2, wellhead protection program, Austin, Nevada: Lander County Sewer and Water District \#2, Austin, Nevada; and Nevada Rural Water Association, Carson City, Nevada, 8 numbered sections.

Lohman, S.W., and others, 1972, Definitions of selected ground-water terms-Revisions and conceptual refinements: U.S. Geological Survey Water-Supply Paper 1988, 21 p.

Lopes, T.J., and Price, C.V., 1997, Study plan for urban stream indicator sites: U.S. Geological Survey Open-File Report 96-25, $15 \mathrm{p}$.

Macdonald, G.A., 1966, Geology of the Cascade Range and Modoc Plateau, in Bailey, E.H, ed., Geology of northern California, California Division of Mines and Geology, Bulletin 190, p. 65-96.

Mathsoft, 2001, S-Plus 6 guide to statistics: Mathsoft, Inc., Seattle, Washington, v. 2622 p.

Maurer, D.K., 1986, Geohydrology and simulated response to ground-water pumpage in Carson Valley-A river-dominated basin in Douglas County, Nevada, and Alpine County, California: U.S. Geological Survey Water-Resources Investigations Report 86-4328, 109 p.

Maurer, D.K., 1993, Hydrogeologic setting and hydrologic data of the Smoke Creek Desert Basin, Washoe County, Nevada, and Lassen County, California, water years 1988-90: U.S. Geological Survey Water-Resources Investigations Report 93-4043, 45 p.

Maurer, D.K., and Berger, D.L., 1997, Subsurface flow and water yield from watersheds tributary to Eagle Valley Hydrographic Area, west-central Nevada: U.S. Geological Survey Water-Resources Investigations Report 97-4191, 56 p.

Maurer, D.K., Berger, D.L., and Prudic, D.E., 1996, Subsurface flow to Eagle Valley from Vicee, Ash, and Kings Canyons, Carson City, Nevada, estimated from Darcy's Law and the chloride-balance method: U.S. Geological Survey Water-Resources Investigations Report 96-4088, 74 p.

Maurer, D.K., Plume, R.W., Thomas, J.M., and Johnson, A.K., 1996, Water Resources and effects of changes in groundwater use along the Carlin Trend, North-Central Nevada: U.S. Geological Survey Water-Resources Investigations Report 96-4134, 146 p.

Maurer, D.K., and Welch, A.H., 2001, Hydrogeology and geochemistry of the Fallon basalt and adjacent aquifers, and potential sources of basalt recharge, in Churchill County, Nevada: U.S. Geological Survey Water-Resources Investigations Report 01-4130, 72 p. 
Maxey, G.B., and Eakin, T.E., 1949, Ground water in White River Valley, White, Nye, and Lincoln Counties, Nevada: Nevada State Engineer, Water Resources Bulletin 8, 59 p.

McDonald and Morrissey Associates, Inc., 1998, Regional hydrologic model, Barrick Goldstrike Mines Inc., Elko and Eureka Counties, Nevada: prepared for Barrick Goldstrike Mines, Inc., McDonald and Morrissey Associates, Inc., Reston, Virginia, 54 p.

McKee, E.H., Wickham, T.A., and Wheeler, K.L., 1998, Evaluation of faults and their effect on ground-water flow southwest of Frenchman Flat, Nye and Clark Counties, Nevada: U.S. Geological Survey Open-File Report 98-580, 14 p.

Mifflin, M.D., 1988, Region 5, Great Basin, in Back, W., Rosenshein, J.S., and Seaber, P.R., eds., Hydrogeology, v. O-2, Geology of North America, 524 p.

Morgan, D.S., and Dettinger, M.D., 1996, Ground-water conditions in Las Vegas Valley, Clark County, Nevada, part 2, hydrogeology and simulation of ground-water flow: U.S. Geological Survey Water-Supply Paper 2320-B, 124 p.

Motts, W.S., Carpenter, David, Groat, C.G., Matz, David, and Walker, R.F., 1970, Geology and hydrology of selected playas in western United States, Ward S. Mott, ed.: Final Scientific Report (Part II), Contract No. AFL 19(628)-2486, Air Force Cambridge Research Laboratories, Bedford, Massachusetts, $286 \mathrm{p}$.

National Atlas of the United States, 1998, Hydrologic Units: compiled by the U.S. Geological Survey, 1:3,500,000 scale map: accessed October 15, 2003 at URL $<$ http://nationalatlas.gov/hucmapwhole.html>.

Nelson, E.P., Kullman, A.J., Gardner, M.H., and Batzle, Michael, 1999, Fault-fracture networks and related fluid flow and sealing, Brushy Canyon Formation, west Texas, in Haneberg, W.C., Mozley, P.S., Moore, J.C., and Goodwin, L.B., eds, Faults and subsurface fluid flow in the shallow crust, Geophysical Monograph 113, American Geophysical Union, Washington, D.C., 222 p.

Nevada Division of Environmental Protection, 2003, Fact Sheet: Accessed December 15, 2003, at URL <http:// ndep.nv.gov/sec/uicfact.pdf>.

Nichols, W.D., 2000, Regional ground-water evapotranspiration and ground-water budgets, Great Basin, Nevada: U.S. Geological Survey Professional Paper 1628, 82 p.

Peterson, F.F., 1981, Landforms of the Basin and Range Province, defined for soil survey: Nevada Agricultural Experiment Station, Technical Bulletin 28, 52 p.

Plume, R.W., 1996, Hydrogeologic framework of the Great Basin region of Nevada, Utah, and adjacent states: U.S. Geological Survey Professional Paper 1409-B, 64 p.

Plume, R.W., and Carlton, S.M., 1988, Hydrogeology of the Great Basin region of Nevada, Utah, and adjacent states: U.S. Geological Survey Hydrologic Investigations Atlas, HA-694-A, 1:1,000,000 scale.

Plummer, L.N., and Friedman, L.C., 1999, Tracing and dating young ground water: U.S. Geological Survey Fact Sheet 134-99.
Porter Geotechnical, 1997, Remediation status report: prepared for Sierra Machinery, Inc, Sparks, Nevada, 9 p.

Prudic, D.E., Harrill, J.R., and Burbey, T.J., 1995, Conceptual evaluation of regional ground-water flow in the carbonaterock province of the Great Basin, Nevada, Utah, and adjacent states: U.S. Geological Survey Professional Paper 1409-D, $102 \mathrm{p}$.

Prudic, D.E., and Herman, M.E., 1996, Ground-water flow and simulated effects of development in Paradise Valley, a basin tributary to the Humboldt River in Humboldt County, Nevada: U.S. Geological Survey Professional Paper 1409-F, $92 \mathrm{p}$.

PTI Environmental Services, Inc., 1994, The hydrogeochemistry of the Robinson Mining District, White Pine County, Nevada, prepared for Magma Mining Company, Tucson, Arizona, 8 numbered sections, 1 appendix.

PTI Environmental Services, Inc., 1997, Effects of pumping the proposed Olinghouse Mine supply well on Dodge Flat and the Truckee River, Washoe County, Nevada: prepared for Bureau of Land Management, Carson City Field Office, PTI Contract CV1T, 02-01, PTI Environmental Services, Boulder, Colorado, $19 \mathrm{p}$.

Rush, F.E., 1968, Index of hydrographic areas: Nevada Division of Water Resources Information Report 6, 38 p.

Rust, B.R., and Koster, E.H., 1984, Coarse alluvial deposits, in Walker, R.G., ed., Facies Models, (2nd ed.): Geoscience Canada, Reprint Series 1, Geological Association of Canada Publications, Toronto, Ontario, Canada, 315 p.

Schwarz, G.E., and Alexander, R.B., 1995, State soil geographic (STATSGO) data base for the conterminous United States: U.S. Geological Survey Open-File Report 95-449, $44 \mathrm{p}$.

Shepherd Miller Inc., 1997, Baseline geochemistry and hydrology for the proposed Olinghouse open-pit gold mine, Washoe County, Nevada: prepared for Alta Gold Company, Shepherd Miller Inc., Fort Collins, Colorado, 9 numbered sections, 10 appendices.

Sigda, J.M., Goodwin, L.B., Mozley, P.S., and Wilson, J.L., 1999, Permeability alteration in small-displacement faults in poorly lithified sediments: Rio Grande Rift, central New Mexico, in Haneberg, W.C., Mozley, P.S., Moore, J.C., and Goodwin, L.B., eds., Faults and subsurface fluid flow in the shallow crust, Geophysical Monograph 113, American Geophysical Union, Washington, D.C., 222 p.

Snyder, C.T., 1962, A hydrologic classification of valleys in the Great Basin, Western United States: International Association Science Hydrology Bulletin, v. 7, no. 3, p. 33-39.

Squillace, P.J., Moran, M.J., Lapham, W.W., Price, C.V., Clawges, R.M., and Zogorski, J.S., 1999, Volatile organic compounds in untreated ambient groundwater of the United States, 1985-1995: Environmental Science \& Technology, v. 33 , no. 23 , p. 4176-4187. 
Star City and Nevada Rural Water Association, 2002, Star City wellhead protection program: Star City Property Owners Association, Winnemucca, Nevada; and Nevada Rural Water Association, Minden, Nevada, 8 numbered sections, 5 appendices.

Stewart, J.H., 1980, Geology of Nevada, a discussion to accompany the geologic map of Nevada: Nevada Bureau of Mines and Geology, Special Publication 4, 136 p.

Stewart, J.H., and Carlson, J.E., 1978a, Geologic map of Nevada: U.S. Geological Survey, prepared in cooperation with the Nevada Bureau of Mines and Geology, 1:500,000 scale, 2 sheets.

Stewart, J.H., and Carlson, J.E., 1978b, Sources of data for geologic map of Nevada: U.S. Geological Survey Miscellaneous Field Studies Map MF-930, 1:1,000,000 scale.

Stewart, J.H., and McKee, E.H., 1977, Geology and mineral deposits of Lander County, Nevada, Geology: Nevada Bureau of Mines and Geology Bulletin 88, pt. I, 59 p.

Tesoriero, A.J., and Voss, F.D., 1997, Predicting the probability of elevated nitrate concentrations in the Puget Sound Basin-Implications for aquifer susceptibility and vulnerability: Ground Water, v. 35, no. 6, p. 1029-1039.

Thomas, J.M., Carlton, S.M., and Hines, L.B., 1989, Groundwater hydrology and simulated effects of development in Smith Creek Valley, a hydrologically closed basin in Lander County, Nevada: U.S. Geological Survey Professional Paper 1409-E, 57 p.

Tschanz, C.M., and Pampeyan, E.H., 1970, Geology and mineral deposits of Lincoln County, Nevada: Nevada Bureau of Mines and Geology Bulletin 73, 188 p.

U.S. Environmental Protection Agency, 2000, Technical assistance document (TAD) for delineating "Other Sensitive Ground Water Areas:" U.S. Environmental Agency, Office of Water, Washington, D.C., EPA/816-R-00-016, 24 p.

U.S. Geological Survey, various dates, 1:100,000-scale digital line graph, U.S. Geological Survey data: accessed January 14, 2004 at URL <http://earthexplorer.usgs.gov>.
U.S. Geological Survey, 2003, Quaternary fault and fold database of the United States: U.S. Geological Survey Open-File Report 03-417: accessed April 20, 2004 at URL

<http://qfaults.cr.usgs.gov/index.htm>.

Vector Engineering, Inc., 1996, Washoe County wellhead protection program: delineation of wellhead protection areas, Hidden Valley water supply wells: Vector Engineering Inc., Carson City, Nevada, 40 p.

Wateresource Consulting Engineers, 1993, Carson City wellhead protection program, Protection area delineation: Wateresource Consulting Engineers, Inc., Reno, Nevada, 6 numbered sections, 3 appendices.

Wateresource Consulting Engineers, Inc., 2000, Wellhead Protection Program for City of Winnemucca: Wateresource Consulting Engineers, Inc., Reno, Nevada, 7 numbered sections.

Widmer, M.C., and Van Hoozer, R.G., 1998, Wellhead protection program, South Truckee Meadows General Improvement District, Washoe County, Nevada: Washoe County Department of Water Resources, Resource Planning and Management Division, Reno, Nevada, $41 \mathrm{p}$.

Winograd, I.J., and Thordarson, William, 1975, Hydrogeologic and hydrochemical framework, south-central Great Basin, Nevada-California, with special reference to the Nevada Test Site: U.S. Geological Survey Professional Paper 712-C, $126 \mathrm{p}$.

Winter, T.C., 2000, The vulnerability of wetlands to climate change: Journal of the American Water Resources Association, v. 36, no. 2, p. 305-311.

Winter, T.C., 2001, The concept of hydrologic landscapes: Journal of the American Water Resources Association, v. 37, no. 2, p. 335-349.

Wolff, R.G., 1982, Physical properties of rocks-Porosity, permeability, distribution coefficients, and dispersivity: U.S. Geological Survey Open-File Report 82-166, 118 p.

Wolock, D.M., 2003, Hydrologic landscape regions of the United States: U.S. Geological Survey Open-File Report 03-145, digital data set: accessed October 15, 2003, at URL $<$ http://water.usgs.gov/lookup/getspatial?hlrus>. 


\section{APPENDIX —Detailed summary of hydraulic conductivity estimates}


[Abbreviations: ft, feet; ft/d, feet per day; nr, not reported.]

\begin{tabular}{|c|c|c|c|c|c|c|c|}
\hline $\begin{array}{c}\text { Hydrogeologic } \\
\text { unit }\end{array}$ & Reference & Location & $\begin{array}{c}\text { Test type/ } \\
\text { data source }\end{array}$ & $\begin{array}{c}\text { Number } \\
\text { of } \\
\text { samples }\end{array}$ & $\begin{array}{c}\text { Mean } \\
\text { geometric - G } \\
\text { arithmetic - A } \\
\text { median - M } \\
\text { (ft/d) }\end{array}$ & $\begin{array}{l}\text { Thickness } \\
\text { tested } \\
\text { (ft) }\end{array}$ & $\begin{array}{l}\text { Range } \\
(\mathrm{ft} / \mathrm{d})\end{array}$ \\
\hline Carbonate rocks, dense & Bedinger and others, 1986, table 1 & Basin and Range & Literature search & $\mathrm{nr}$ & $0.01-\mathrm{G}$ & $\mathrm{nr}$ & ${ }^{a} 2 \times 10^{-3}$ to $7 \times 10^{-2}$ \\
\hline $\begin{array}{l}\text { Carbonate rocks, fractured, } \\
\text { karstic }\end{array}$ & Bedinger and others, 1986 , table 1 & Basin and Range & Literature search & $\mathrm{nr}$ & $200-\mathrm{G}$ & $\mathrm{nr}$ & ${ }^{\mathrm{a}} 10$ to 300 \\
\hline Carbonate rocks, unfaulted & Belcher and others, 2001, table 2 & Southern Nevada & Pumping test & 19 & $\begin{array}{c}0.3-\mathrm{G} \\
6-\mathrm{A}\end{array}$ & 30 to 1,700 & $3 \times 10^{-4}$ to 50 \\
\hline $\begin{array}{l}\text { Carbonate rocks, faulted and } \\
\text { karstic }\end{array}$ & Belcher and others, 2001, table 2 & Southern Nevada & Pumping test & 18 & $\begin{array}{r}10-\mathrm{G} \\
400-\mathrm{A}\end{array}$ & 30 to 1,700 & 0.03 to 2700 \\
\hline Carbonate rocks & Belcher and others, 2001, table 2 & Southern Nevada & Pumping test & 51 & $\begin{array}{c}2-\mathrm{G} \\
300-\mathrm{A}\end{array}$ & 30 to 1,700 & $3 \times 10^{-5}$ to 2700 \\
\hline Carbonate rocks & D'Agnese and others, 1997, p. 17 & Basin and Range & Literature search & $\mathrm{nr}$ & $\mathrm{nr}$ & $\mathrm{nr}$ & $2 \times 10^{-3}$ to 3300 \\
\hline Carbonate rocks & $\begin{array}{l}\text { McDonald and Morrissey } \\
\text { Associates, Inc, 1998, table } 2\end{array}$ & Near Carlin, Nevada & Pumping test & 9 & $\mathrm{nr}$ & $\mathrm{nr}$ & 3 to 370 \\
\hline Carbonate rocks & Geomega Inc., 1997, table 5-1 & $\begin{array}{l}\text { Near McGill, } \\
\text { Nevada }\end{array}$ & Pumping test & $\mathrm{nr}$ & $\mathrm{nr}$ & $\mathrm{nr}$ & 1.1 to 15 \\
\hline Carbonate rocks & Geomega Inc, 1998a, p. 24-26 & $\begin{array}{l}\text { Crescent Valley, } \\
\text { Nevada }\end{array}$ & Pumping test & 1 & $\mathrm{nr}$ & 1,500 & 25 to 94 \\
\hline Carbonate rocks & Geomega Inc, 1998a, p. 24-26 & $\begin{array}{l}\text { Crescent Valley, } \\
\text { Nevada }\end{array}$ & Pumping test & 4 & $350-\mathrm{A}$ & 20 & 130 to 530 \\
\hline $\begin{array}{l}\text { Carbonate rocks, } \\
\text { metamorphosed }\end{array}$ & Geomega Inc, 1998 b, p. 3-3 & Near Ruth, Nevada & Pumping test & 1 & $\mathrm{~b}_{0.01}$ & $\mathrm{nr}$ & $\mathrm{nr}$ \\
\hline $\begin{array}{l}\text { Carbonate rocks, } \\
\text { unmetamorphosed }\end{array}$ & Geomega Inc, 1998b, p. 3-3 & Near Ruth, Nevada & Pumping test & 1 & $\mathrm{~b}_{17}$ & $\mathrm{nr}$ & $\mathrm{nr}$ \\
\hline Carbonate rocks & Plume, 1996, p. B13 & Near Test Site & Pumping test & 10 & $\begin{array}{c}80-\mathrm{A} \\
6-\mathrm{M}\end{array}$ & $\mathrm{nr}$ & 0.7 to 700 \\
\hline Carbonate rocks & Plume, 1996, p. B13 & Eastern Nevada & Pumping test & 4 & $\begin{array}{c}200-\mathrm{A} \\
9-\mathrm{M}\end{array}$ & $\mathrm{nr}$ & 0.1 to 900 \\
\hline
\end{tabular}




\begin{tabular}{|c|c|c|c|c|c|c|c|}
\hline $\begin{array}{l}\text { Hydrogeologic } \\
\text { unit }\end{array}$ & Reference & Location & $\begin{array}{l}\text { Test type/ } \\
\text { data source }\end{array}$ & $\begin{array}{l}\text { Number } \\
\text { of } \\
\text { samples }\end{array}$ & $\begin{array}{c}\text { Mean } \\
\text { geometric - G } \\
\text { arithmetic - A } \\
\text { median - M } \\
\text { (ft/d) }\end{array}$ & $\begin{array}{l}\text { Thickness } \\
\text { tested } \\
\text { (ft) }\end{array}$ & $\begin{array}{l}\text { Range } \\
\text { (ft/d) }\end{array}$ \\
\hline Carbonate rocks & Plume, 1996, p. B13 & Eastern Great Basin & Drill-Stem test & 8 & $\begin{array}{c}0.1-\mathrm{A} \\
0.001-\mathrm{M}\end{array}$ & $\mathrm{nr}$ & $5 \times 10^{-4}$ to 0.1 \\
\hline Carbonate rocks & $\begin{array}{l}\text { PTI Environmental Services, Inc., } \\
\text { 1994, table 6-6 }\end{array}$ & Near Ruth, Nevada & $\begin{array}{l}\text { Pumping test, } \\
\text { literature search }\end{array}$ & $\mathrm{nr}$ & $\mathrm{nr}$ & $\mathrm{nr}$ & 1.1 to 26 \\
\hline $\begin{array}{l}\text { Quaternary to Tertiary-age } \\
\text { volcanic flows: Basalt, dense }\end{array}$ & Bedinger and others, 1986 , table 1 & Basin and Range & Literature search & $\mathrm{nr}$ & $1 \times 10^{-3}-\mathrm{G}$ & $\mathrm{nr}$ & a $2 \times 10^{-4}$ to 0.01 \\
\hline $\begin{array}{l}\text { Quaternary to Tertiary-age } \\
\text { volcanic flows: Basalt, } \\
\text { fractured and cavernous }\end{array}$ & Bedinger and others, 1986, table 1 & Basin and Range & Literature search & $\mathrm{nr}$ & 2 & $\mathrm{nr}$ & ${ }^{\mathrm{a}} 0.07$ to 30 \\
\hline $\begin{array}{l}\text { Quaternary to Tertiary-age } \\
\text { volcanic flows: Basalt }\end{array}$ & Belcher and others, 2001, table 2 & Southern Nevada & $\begin{array}{l}\text { Pumping and } \\
\text { slug test }\end{array}$ & 2 & $\mathrm{nr}$ & 200 to 260 & 0.07 to 13 \\
\hline $\begin{array}{l}\text { Quaternary to Tertiary-age } \\
\text { volcanic flows: Basalt }\end{array}$ & D'Agnese and others, 1997, p. 17 & Basin and Range & Literature search & $\mathrm{nr}$ & $\mathrm{nr}$ & $\mathrm{nr}$ & $2 \times 10^{-4}$ to 3 \\
\hline $\begin{array}{l}\text { Quaternary to Tertiary-age } \\
\text { volcanic flows: Basalt }\end{array}$ & Handman and others, 1990, p. 15 & $\begin{array}{l}\text { Honey Lake Valley, } \\
\text { Nevada and } \\
\text { California }\end{array}$ & Pumping test & $\mathrm{nr}$ & $\mathrm{nr}$ & $\mathrm{nr}$ & $>100$ \\
\hline $\begin{array}{l}\text { Quaternary to Tertiary-age } \\
\text { volcanic flows: Basalt }\end{array}$ & $\begin{array}{l}\text { Hydrologic Consultants, Inc., } 2000 \text {, } \\
\text { table } 6\end{array}$ & Near Valmy, Nevada & Modeled value & $\mathrm{nr}$ & $1^{b}$ & $\mathrm{nr}$ & $\mathrm{nr}$ \\
\hline $\begin{array}{l}\text { Quaternary to Tertiary-age } \\
\text { volcanic flows: Basalt }\end{array}$ & Maurer and Berger, 1997, p. 11 & $\begin{array}{l}\text { Eagle Valley, } \\
\text { Nevada }\end{array}$ & Slug test & 2 & $\mathrm{nr}$ & 4 to 30 & 3 to 500 \\
\hline $\begin{array}{l}\text { Quaternary to Tertiary-age } \\
\text { volcanic flows: Basalt }\end{array}$ & Maurer and Welch, 2001, p. 25 & $\begin{array}{l}\text { Carson Desert, } \\
\text { Nevada }\end{array}$ & $\begin{array}{l}\text { Pumping test/ } \\
\text { slug test }\end{array}$ & 3 & $\mathrm{nr}$ & $\mathrm{nr}$ & 260 to 850 \\
\hline $\begin{array}{l}\text { Quaternary to Tertiary-age } \\
\text { volcanic flows: Basalt }\end{array}$ & Plume, 1996, p. B20 & Great Basin & Pumping test & $\mathrm{nr}$ & $\mathrm{nr}$ & $\mathrm{nr}$ & 130 to 1,300 \\
\hline $\begin{array}{l}\text { Quaternary to Tertiary-age } \\
\text { volcanic flows: Basalt }\end{array}$ & $\begin{array}{l}\text { Shepherd Miller Consultants, } 1997 \text {, } \\
\text { p. 3-5 }\end{array}$ & $\begin{array}{l}\text { Near Fernley, } \\
\text { Nevada }\end{array}$ & Pumping test & $\mathrm{nr}$ & $0.3-\mathrm{G}$ & $\mathrm{nr}$ & 0.03 to 2 \\
\hline $\begin{array}{l}\text { Quaternary to Tertiary-age } \\
\text { volcanic flows: Basalt }\end{array}$ & $\begin{array}{l}\text { Wateresource Consulting Engineers, } \\
2000 \text {, p. } 13\end{array}$ & $\begin{array}{l}\text { Near Winnemucca, } \\
\text { Nevada }\end{array}$ & Pumping test & 2 & $\mathrm{nr}$ & 26 to 100 & 90 to 340 \\
\hline
\end{tabular}




\begin{tabular}{|c|c|c|c|c|c|c|c|}
\hline $\begin{array}{c}\text { Hydrogeologic } \\
\text { unit }\end{array}$ & Reference & Location & $\begin{array}{l}\text { Test type/ } \\
\text { data source }\end{array}$ & $\begin{array}{l}\text { Number } \\
\text { of } \\
\text { samples }\end{array}$ & $\begin{array}{c}\text { Mean } \\
\text { geometric - G } \\
\text { arithmetic - A } \\
\text { median - M } \\
\text { (ft/d) }\end{array}$ & $\begin{array}{l}\text { Thickness } \\
\text { tested } \\
\text { (ft) }\end{array}$ & $\begin{array}{l}\text { Range } \\
(\mathrm{ft} / \mathrm{d})\end{array}$ \\
\hline $\begin{array}{l}\text { Quaternary to Tertiary-age } \\
\text { volcanic flows: Rhyolite, } \\
\text { dense }\end{array}$ & Bedinger and others, 1986, table 1 & Basin and Range & Literature search & $\mathrm{nr}$ & $1 \times 10^{-3}-\mathrm{G}$ & $\mathrm{nr}$ & a $2 \times 10^{-4}$ to .01 \\
\hline $\begin{array}{l}\text { Quaternary to Tertiary-age } \\
\text { volcanic flows: Rhyolite, } \\
\text { fractured }\end{array}$ & Bedinger and others, 1986, table 1 & Basin and Range & Literature search & $\mathrm{nr}$ & 2 & $\mathrm{nr}$ & ${ }^{\mathrm{a}} 0.07$ to 30 \\
\hline $\begin{array}{l}\text { Quaternary to Tertiary-age } \\
\text { volcanic flows: Rhyolite }\end{array}$ & Belcher and others, 2001, table 2 & Southern Nevada & Pumping test & 25 & $\begin{array}{l}0.3-\mathrm{G} \\
0.6-\mathrm{A}\end{array}$ & 23 to 5000 & $2 \times 10^{-5}$ to 13 \\
\hline $\begin{array}{l}\text { Quaternary to Tertiary-age } \\
\text { volcanic flows: Rhyolite }\end{array}$ & D'Agnese and others, 1997, table 1 & Basin and Range & Literature search & $\mathrm{nr}$ & $\mathrm{nr}$ & $\mathrm{nr}$ & $2 \times 10^{-4}$ to 3 \\
\hline $\begin{array}{l}\text { Quaternary to Tertiary-age } \\
\text { volcanic flows: Rhyolite }\end{array}$ & $\begin{array}{l}\text { McDonald and Morrissey } \\
\text { Associates, Inc., 1998, table } 2\end{array}$ & Near Carlin, Nevada & Pumping test & 6 & $\mathrm{nr}$ & $40-640$ & 1 to 260 \\
\hline $\begin{array}{l}\text { Quaternary to Tertiary-age } \\
\text { volcanic flows: Rhyolite }\end{array}$ & $\begin{array}{l}\text { PTI Environmental Services, Inc., } \\
\text { 1994, table 6-6 }\end{array}$ & Near Ruth, Nevada & Pumping test & $\mathrm{nr}$ & $\mathrm{nr}$ & $\mathrm{nr}$ & 0.01 to 0.06 \\
\hline $\begin{array}{l}\text { Quaternary to Tertiary-age } \\
\text { volcanic flows: Andesite }\end{array}$ & $\begin{array}{l}\text { Consulting Services Associates, Inc, } \\
\text { 1997, interpreted by K. Halford, } \\
\text { U.S. Geological Survey, } \\
\text { written commun., } 2001\end{array}$ & Near Tracy, Nevada & Pumping test & 1 & $\mathrm{nr}$ & 220 & 40 to 60 \\
\hline $\begin{array}{l}\text { Quaternary to Tertiary-age } \\
\text { volcanic flows: Andesite }\end{array}$ & D'Agnese and others, 1997, p. 17 & Basin and Range & Literature search & $\mathrm{nr}$ & $\mathrm{nr}$ & $\mathrm{nr}$ & $2 \times 10^{-4}$ to 3 \\
\hline $\begin{array}{l}\text { Quaternary to Tertiary-age } \\
\text { volcanic flows: Andesite }\end{array}$ & Shepherd Miller Inc, 1997, p. 3-5 & $\begin{array}{l}\text { Near Fernley, } \\
\text { Nevada }\end{array}$ & Pumping test & $\mathrm{nr}$ & $0.3-\mathrm{G}$ & $\mathrm{nr}$ & 0.03 to 2 \\
\hline $\begin{array}{l}\text { Breccias, Tuffs, and volcanic } \\
\text { rocks older than Tertiary-age: } \\
\text { Tuff, welded and fractured }\end{array}$ & Bedinger and others, 1986, table 1 & Basin and Range & Literature search & $\mathrm{nr}$ & $3-\mathrm{G}$ & $\mathrm{nr}$ & 1 to 16 \\
\hline Breccias, Tuffs, and volcanic & Bedinger and others, 1986 , table 1 & Basin and Range & Literature search & $\mathrm{nr}$ & $1 \times 10^{-3}-\mathrm{G}$ & $\mathrm{nr}$ & $1 \times 10^{-4}$ to 0.02 \\
\hline
\end{tabular}




\begin{tabular}{|c|c|c|c|c|c|c|c|}
\hline $\begin{array}{l}\text { Hydrogeologic } \\
\text { unit }\end{array}$ & Reference & Location & $\begin{array}{c}\text { Test type/ } \\
\text { data source }\end{array}$ & $\begin{array}{c}\text { Number } \\
\text { of } \\
\text { samples }\end{array}$ & $\begin{array}{c}\text { Mean } \\
\text { geometric - G } \\
\text { arithmetic - A } \\
\text { median - M } \\
(\mathrm{ft} / \mathrm{d})\end{array}$ & $\begin{array}{l}\text { Thickness } \\
\text { tested } \\
\text { (ft) }\end{array}$ & $\begin{array}{l}\text { Range } \\
\text { (ft/d) }\end{array}$ \\
\hline $\begin{array}{l}\text { Breccias, Tuffs, and volcanic } \\
\text { rocks older than Tertiary-age: } \\
\text { Tuff, non-welded }\end{array}$ & Bedinger and others, 1986 , table 1 & Basin and Range & Literature search & $\mathrm{nr}$ & $1 \times 10^{-4}-\mathrm{G}$ & $\mathrm{nr}$ & $7 \times 10^{-5}$ to 0.02 \\
\hline $\begin{array}{l}\text { Breccias, Tuffs, and volcanic } \\
\text { rocks older than Tertiary-age: } \\
\text { Tuff, ash-flow }\end{array}$ & Belcher and others, 2001, table 2 & Southern Nevada & Pumping test & 109 & $\begin{array}{l}0.3-\mathrm{G} \\
16-\mathrm{A}\end{array}$ & 30 to 5000 & $7 \times 10^{-5}$ to 600 \\
\hline $\begin{array}{l}\text { Breccias, Tuffs, and volcanic } \\
\text { rocks older than Tertiary-age: } \\
\text { Tuff breccia }\end{array}$ & Belcher and others, 2001, table 2 & Southern Nevada & Pumping test & 11 & $\begin{array}{r}1-\mathrm{G} \\
13-\mathrm{A}\end{array}$ & 30 to 5000 & $3 \times 10^{-3}$ to 50 \\
\hline $\begin{array}{l}\text { Breccias, Tuffs, and volcanic } \\
\text { rocks older than Tertiary-age: } \\
\text { older volcanic rocks }\end{array}$ & Belcher and others, 2001, table 2 & Southern Nevada & Pumping test & 46 & $\begin{array}{c}0.01-\mathrm{G} \\
0.2-\mathrm{A}\end{array}$ & 30 to 5000 & $3 \times 10^{-5}$ to 3 \\
\hline $\begin{array}{l}\text { Breccias, Tuffs, and volcanic } \\
\text { rocks older than Tertiary-age: } \\
\text { Tuff, ash-flow }\end{array}$ & D'Agnese and others, 1997 , table 1 & Basin and Range & Literature search & $\mathrm{nr}$ & $\mathrm{nr}$ & $\mathrm{nr}$ & $2 \times 10^{-4}$ to 16 \\
\hline $\begin{array}{l}\text { Breccias, Tuffs, and volcanic } \\
\text { rocks older than Tertiary-age: } \\
\text { Tuff }\end{array}$ & $\begin{array}{l}\text { Errol L. Montgomery \& Associates, } \\
\text { Inc., 1988, p. } 21\end{array}$ & $\begin{array}{l}\text { Desert Valley, } \\
\text { Nevada }\end{array}$ & Pumping test & 1 & $\mathrm{~b}_{45}$ & 200 & $\mathrm{nr}$ \\
\hline $\begin{array}{l}\text { Breccias, Tuffs, and volcanic } \\
\text { rocks older than Tertiary-age: } \\
\text { Tuff }\end{array}$ & $\begin{array}{l}\text { Groundwater Resources } \\
\text { Consultants, Inc., 1994, p. } 20\end{array}$ & $\begin{array}{l}\text { Warm Springs } \\
\text { Valley, Nevada }\end{array}$ & $\begin{array}{l}\text { Pumping and } \\
\text { slug test }\end{array}$ & 27 & $0.4-\mathrm{G}$ & $\mathrm{nr}$ & 0.1 to 40 \\
\hline $\begin{array}{l}\text { Breccias, Tuffs, and volcanic } \\
\text { rocks older than Tertiary-age: } \\
\text { Tuff }\end{array}$ & Plume 1996, p. B20 & Nevada Test Site & Pumping test & $\mathrm{nr}$ & $\mathrm{nr}$ & $\mathrm{nr}$ & 1.5 to 17 \\
\hline $\begin{array}{l}\text { Breccias, Tuffs, and volcanic } \\
\text { rocks older than Tertiary-age: } \\
\text { older volcanic rocks }\end{array}$ & Plume 1996, p. B20 & $\begin{array}{l}\text { Railroad and White } \\
\text { River Valleys, } \\
\text { Nevada }\end{array}$ & Drill-stem tests & 54 & $\begin{array}{c}0.02-\mathrm{A} \\
4 \times 10^{-4}-\mathrm{M}\end{array}$ & $\mathrm{nr}$ & $1 \times 10^{-6}$ to 0.3 \\
\hline $\begin{array}{l}\text { Breccias, Tuffs, and volcanic } \\
\text { rocks older than Tertiary-age: } \\
\text { Tuff }\end{array}$ & Wolff, 1982, p. 51-52 & Nevada Test Site & Lab test & 128 & $\begin{array}{l}8 \times 10^{-6} \text { to } \\
6 \times 10^{-2}-\mathrm{A}\end{array}$ & $\mathrm{nr}$ & $3 \times 10-7$ to 0.2 \\
\hline
\end{tabular}




\begin{tabular}{|c|c|c|c|c|c|c|c|}
\hline $\begin{array}{c}\text { Hydrogeologic } \\
\text { unit }\end{array}$ & Reference & Location & $\begin{array}{l}\text { Test type/ } \\
\text { data source }\end{array}$ & $\begin{array}{c}\text { Number } \\
\text { of } \\
\text { samples }\end{array}$ & $\begin{array}{c}\text { Mean } \\
\text { geometric - G } \\
\text { arithmetic - A } \\
\text { median - M } \\
\text { (ft/d) }\end{array}$ & $\begin{array}{c}\text { Thickness } \\
\text { tested } \\
\text { (ft) }\end{array}$ & $\begin{array}{l}\text { Range } \\
\text { (ft/d) }\end{array}$ \\
\hline $\begin{array}{l}\text { Intrusive and metamorphic } \\
\text { rocks, weathered }\end{array}$ & Bedinger and others, 1986, table 1 & Basin and Range & Literature search & $\mathrm{nr}$ & $0.1-\mathrm{G}$ & $\mathrm{nr}$ & ${ }^{\mathrm{a}} 7 \times 10^{-3}$ to 1 \\
\hline $\begin{array}{l}\text { Intrusive and metamorphic } \\
\text { rocks, less than } 1,000 \mathrm{ft} \text { deep }\end{array}$ & Bedinger and others, 1986, table 1 & Basin and Range & Literature search & $\mathrm{nr}$ & $2 \times 10^{-3}-\mathrm{G}$ & $\mathrm{nr}$ & $\mathrm{a}_{2 \times 10^{-5}}$ to .07 \\
\hline $\begin{array}{l}\text { Intrusive and metamorphic } \\
\text { rocks, more than 1,000-ft deep }\end{array}$ & Bedinger and others, 1986, table 1 & Basin and Range & Literature search & $\mathrm{nr}$ & $1 \times 10^{-6}-\mathrm{G}$ & $\mathrm{nr}$ & ${ }^{\mathrm{a}} 7 \times 10^{-8}$ to $2 \times 10^{-5}$ \\
\hline $\begin{array}{l}\text { Intrusive and metamorphic } \\
\text { rocks }\end{array}$ & Belcher and others, 2001, table 2 & Southern Nevada & Pumping test & 7 & $\begin{array}{c}0.01-\mathrm{G} \\
1-\mathrm{A}\end{array}$ & 30 to 1400 & $2 \times 10^{-2}$ to 3 \\
\hline $\begin{array}{l}\text { Intrusive and metamorphic } \\
\text { rocks }\end{array}$ & D'Agnese and others, 1997, table 1 & Basin and Range & Literature search & $\mathrm{nr}$ & $\mathrm{nr}$ & $\mathrm{nr}$ & $7 \times 10^{-8}$ to 0.2 \\
\hline $\begin{array}{l}\text { Intrusive and metamorphic } \\
\text { rocks }\end{array}$ & $\begin{array}{l}\text { GTE California, Inc., 1998, } \\
\text { appendix C }\end{array}$ & $\begin{array}{l}\text { Near Topaz Lake, } \\
\text { Nevada }\end{array}$ & Pumping test & 9 & $\mathrm{nr}$ & $\mathrm{nr}$ & 0.05 to 4 \\
\hline $\begin{array}{l}\text { Intrusive and metamorphic } \\
\text { rocks }\end{array}$ & $\begin{array}{l}\text { Hydrologic Consultants, Inc., 2000, } \\
\text { table } 6\end{array}$ & Near Valmy, Nevada & Modeled value & $\mathrm{nr}$ & $\mathrm{b}_{0.01}$ & $\mathrm{nr}$ & $\mathrm{nr}$ \\
\hline $\begin{array}{l}\text { Intrusive and metamorphic } \\
\text { rocks }\end{array}$ & $\begin{array}{l}\text { Maurer, Berger, and Prudic, 1996, } \\
\text { p. } 21\end{array}$ & $\begin{array}{l}\text { Near Eagle Valley, } \\
\text { Nevada }\end{array}$ & Slug test & 4 & $\mathrm{nr}$ & 10 & 2 to 4 \\
\hline $\begin{array}{l}\text { Intrusive and metamorphic } \\
\text { rocks }\end{array}$ & Maurer and Berger, 1997, p. 11 & $\begin{array}{l}\text { Near Eagle Valley, } \\
\text { Nevada }\end{array}$ & Slug test & 11 & $\mathrm{nr}$ & 20 to 30 & 0.01 to 30 \\
\hline $\begin{array}{l}\text { Intrusive and metamorphic } \\
\text { rocks }\end{array}$ & $\begin{array}{l}\text { McDonald and Morrissey } \\
\text { Associates, Inc., 1998, table } 2\end{array}$ & Near Carlin, Nevada & Pumping test & 1 & $\mathrm{~b}_{3}$ & 1200 & $\mathrm{nr}$ \\
\hline Clastic rocks: Sandstone & Bedinger and others, 1986, table 1 & Basin and Range & Literature search & $\mathrm{nr}$ & $0.1-\mathrm{G}$ & $\mathrm{nr}$ & 0.02 to 1 \\
\hline Clastic rocks: Sandstone & Belcher and others, 2001, table 2 & Southern Nevada & Pumping test & 16 & $\begin{array}{l}7 \times 10^{-3}-\mathrm{G} \\
0.02-\mathrm{A}\end{array}$ & 10 to 100 & $7 \times 10^{-4}$ to 1 \\
\hline Clastic rocks: Sandstone & D'Agnese and others, 1997, table 1 & Basin and Range & Literature search & $\mathrm{nr}$ & $\mathrm{nr}$ & $\mathrm{nr}$ & 0.02 to 1 \\
\hline Clastic rocks: Sandstone & $\begin{array}{l}\text { PTI Environmental Services, Inc., } \\
\text { 1994, table 6-6 }\end{array}$ & Near Ruth, Nevada & Pumping test & $\mathrm{nr}$ & $\mathrm{nr}$ & $\mathrm{nr}$ & $9 \times 10^{-3}$ to 0.6 \\
\hline Clastic rocks: Sandstone & Wolff, 1982, p. 41 & Nevada Test Site & Lab test & 1 & $\mathrm{~b}_{18}$ & $\mathrm{nr}$ & $\mathrm{nr}$ \\
\hline Clastic rocks: Siltstone & Bedinger and others, 1986, table 1 & Basin and Range & Literature search & $\mathrm{nr}$ & $2 \times 10^{-6}-G$ & $\mathrm{nr}$ & ${ }^{\mathrm{a}} 1 \times 10^{-7}$ to $3 \times 10^{-5}$ \\
\hline
\end{tabular}




\begin{tabular}{|c|c|c|c|c|c|c|c|}
\hline $\begin{array}{c}\text { Hydrogeologic } \\
\text { unit }\end{array}$ & Reference & Location & $\begin{array}{l}\text { Test type/ } \\
\text { data source }\end{array}$ & $\begin{array}{c}\text { Number } \\
\text { of } \\
\text { samples }\end{array}$ & $\begin{array}{c}\text { Mean } \\
\text { geometric - G } \\
\text { arithmetic - A } \\
\text { median - M } \\
\text { (ft/d) }\end{array}$ & $\begin{array}{l}\text { Thickness } \\
\text { tested } \\
\text { (ft) }\end{array}$ & $\begin{array}{c}\text { Range } \\
\text { (ft/d) }\end{array}$ \\
\hline Clastic rocks: Siltstone & Belcher and others, 2001, table 2 & Southern Nevada & Pumping test & 30 & $\begin{array}{l}1 \times 10^{-4}-\mathrm{G} \\
0.7-\mathrm{A}\end{array}$ & 50 to 4,200 & $1 \times 10^{-7}$ to 16 \\
\hline Clastic rocks: Siltstone & D'Agnese and others, 1997, table 1 & Basin and Range & Literature search & $\mathrm{nr}$ & $\mathrm{nr}$ & $\mathrm{nr}$ & $7 \times 10^{-8}$ to 0.2 \\
\hline Clastic rocks: Siltstone & $\begin{array}{l}\text { Hydrologic Consultants, Inc., 2000, } \\
\text { table } 6\end{array}$ & Near Valmy Nevada & Modeled value & $\mathrm{nr}$ & $\mathrm{nr}$ & $\mathrm{nr}$ & 0.08 to 4 \\
\hline Clastic rocks: Siltstone & $\begin{array}{l}\text { McDonald and Morrissey } \\
\text { Associates, Inc., 1998, table } 2\end{array}$ & Near Carlin, Nevada & Pumping test & 26 & $\mathrm{nr}$ & 200 to 1000 & 0.04 to 3 \\
\hline Clastic rocks: Siltstone & $\begin{array}{l}\text { PTI Environmental Services, Inc., } \\
\text { 1994, table 6-6 }\end{array}$ & Near Ruth, Nevada & Pumping test & $\mathrm{nr}$ & $\mathrm{nr}$ & $\mathrm{nr}$ & less than 0.3 \\
\hline Clastic rocks: Shale & $\begin{array}{l}\text { PTI Environmental Services, Inc., } \\
\text { 1994, table 6-6 }\end{array}$ & Near Ruth, Nevada & Pumping test & $\mathrm{nr}$ & $\mathrm{nr}$ & $\mathrm{nr}$ & less than $2 \times 10-{ }^{4}$ \\
\hline Clastic rocks: Siltstone & Wolff, 1982, p. 41 & Nevada Test Site & Lab test & 6 & $\mathrm{nr}$ & $\mathrm{nr}$ & $2 \times 10^{-9}$ to $1 \times 10^{-5}$ \\
\hline $\begin{array}{l}\text { Tertiary tuffaceous rocks and } \\
\text { sediment }\end{array}$ & Belcher and others, 2001, table 2 & Southern Nevada & Pumping test & 15 & $\begin{array}{l}0.2-\mathrm{G} \\
5-\mathrm{A}\end{array}$ & 30 to 230 & $1 \times 10^{-3}$ to 20 \\
\hline $\begin{array}{l}\text { Tertiary tuffaceous rocks and } \\
\text { sediment }\end{array}$ & D'Agnese and others, 1997, table 1 & Basin and Range & Literature search & $\mathrm{nr}$ & $\mathrm{nr}$ & $\mathrm{nr}$ & $2 \times 10^{-4}$ to 0.02 \\
\hline $\begin{array}{l}\text { Tertiary tuffaceous rocks and } \\
\text { sediment }\end{array}$ & Maurer, 1986, p. 29 & $\begin{array}{l}\text { Carson Valley, } \\
\text { Nevada }\end{array}$ & Specific capacity & $\mathrm{nr}$ & $\mathrm{b}_{0.9}$ & $\mathrm{nr}$ & $\mathrm{nr}$ \\
\hline $\begin{array}{l}\text { Tertiary tuffaceous rocks and } \\
\text { sediment }\end{array}$ & $\begin{array}{l}\text { McDonald and Morrissey } \\
\text { Associates, Inc., 1998, table } 2\end{array}$ & Near Carlin, Nevada & Pumping test & 5 & $\mathrm{nr}$ & 200 to 1,000 & 0.05 to 3 \\
\hline $\begin{array}{l}\text { Unconsolidated sediments: } \\
\text { Fluvial deposits }\end{array}$ & $\begin{array}{l}\text { Belcher and others, 2001, } \\
\text { Appendix A }\end{array}$ & Southern Nevada & Pumping test & 5 & $\mathrm{nr}$ & 50 & 9 to 16 \\
\hline $\begin{array}{l}\text { Unconsolidated sediments: } \\
\text { Fluvial deposits }\end{array}$ & Bredehoeft, 1963, p. 46 & $\begin{array}{l}\text { Lower Humboldt } \\
\text { River Basin }\end{array}$ & Specific capacity & 22 & $135-\mathrm{A}$ & 40 to 300 & 20 to 1000 \\
\hline $\begin{array}{l}\text { Unconsolidated sediments: } \\
\text { Fluvial deposits }\end{array}$ & Berger, 1995, p. 22 & $\begin{array}{l}\text { Desert Valley, } \\
\text { Nevada }\end{array}$ & Specific capacity & 1 & $\mathrm{nr}$ & $\mathrm{nr}$ & 140 \\
\hline $\begin{array}{l}\text { Unconsolidated sediments: } \\
\text { Fluvial deposits }\end{array}$ & $\begin{array}{l}\text { Camp Dresser \& McKee, Inc., 1996, } \\
\text { table } 2\end{array}$ & $\begin{array}{l}\text { Near Sparks, } \\
\text { Nevada }\end{array}$ & Pumping test & 35 & $\mathrm{nr}$ & 15 to 60 & 6 to 140 \\
\hline
\end{tabular}




\begin{tabular}{|c|c|c|c|c|c|c|c|}
\hline $\begin{array}{l}\text { Hydrogeologic } \\
\text { unit }\end{array}$ & Reference & Location & $\begin{array}{l}\text { Test type/ } \\
\text { data source }\end{array}$ & $\begin{array}{l}\text { Number } \\
\text { of } \\
\text { samples }\end{array}$ & $\begin{array}{c}\text { Mean } \\
\text { geometric - G } \\
\text { arithmetic - A } \\
\text { median - M } \\
\text { (ft/d) }\end{array}$ & $\begin{array}{l}\text { Thickness } \\
\text { tested } \\
\text { (ft) }\end{array}$ & $\begin{array}{l}\text { Range } \\
\text { (ft/d) }\end{array}$ \\
\hline $\begin{array}{l}\text { Unconsolidated sediments: } \\
\text { Fluvial deposits }\end{array}$ & Geomega, Inc., 1998a, p. 22 & Near Ruth, Nevada & Pumping test & several & $\mathrm{nr}$ & 350 & 4 to 2,200 \\
\hline $\begin{array}{l}\text { Unconsolidated sediments: } \\
\text { Fluvial deposits }\end{array}$ & $\begin{array}{l}\text { PTI Environmental Services, Inc., } \\
\text { 1997, p. } 8\end{array}$ & $\begin{array}{l}\text { Near Fernley, } \\
\text { Nevada }\end{array}$ & Pumping test & 10 & $113-\mathrm{G}$ & 11 to 56 & 10 to 1,200 \\
\hline $\begin{array}{l}\text { Unconsolidated sediments: } \\
\text { Fluvial deposits }\end{array}$ & Vector Engineering, Inc., 1996, p. 25 & $\begin{array}{l}\text { Near Hidden Valley, } \\
\text { Nevada }\end{array}$ & Pumping test & 19 & $\mathrm{nr}$ & $\mathrm{nr}$ & 4 to 65 \\
\hline $\begin{array}{l}\text { Unconsolidated sediments: } \\
\text { Basin-fill - coarse, medium, } \\
\text { and fine grained }\end{array}$ & Morgan and Dettinger, 1996, p. B56 & $\begin{array}{l}\text { Las Vegas Valley, } \\
\text { Nevada }\end{array}$ & Pumping test & 25 & $\mathrm{nr}$ & $\mathrm{nr}$ & $\begin{array}{l}\text { Coarse }-15 \\
\text { Medium - } 1 \\
\text { Fine }-0.1\end{array}$ \\
\hline $\begin{array}{l}\text { Unconsolidated sediments: } \\
\text { Basin-fill, coarse-grained }\end{array}$ & Bedinger and others, 1986, table 1 & Basin and Range & Literature search & $\mathrm{nr}$ & $30-\mathrm{G}$ & $\mathrm{nr}$ & a 3 to 230 \\
\hline $\begin{array}{l}\text { Unconsolidated sediments: } \\
\text { Basin-fill, fine-grained }\end{array}$ & Bedinger and others, 1986, table 1 & Basin and Range & Literature search & $\mathrm{nr}$ & $7 \times 10^{-4}-\mathrm{G}$ & $\mathrm{nr}$ & ${ }^{a} 3 \times 10^{-5}$ to $7 \times 10^{-3}$ \\
\hline $\begin{array}{l}\text { Unconsolidated sediments: } \\
\text { Basin-fill undifferentiated }\end{array}$ & Aquifer Science, Inc., 2001, p. 3-8 & $\begin{array}{l}\text { Eagle Valley, } \\
\text { Nevada }\end{array}$ & Pumping test & 5 & $\mathrm{nr}$ & $\mathrm{nr}$ & 4 to 12 \\
\hline $\begin{array}{l}\text { Unconsolidated sediments: } \\
\text { Basin-fill undifferentiated }\end{array}$ & Belcher and others, 2001, table 2 & Southern Nevada & Pumping test & 43 & $\begin{array}{r}2-\mathrm{G} \\
11-\mathrm{A}\end{array}$ & 20 to 500 & $1 \times 10^{-3}$ to 130 \\
\hline $\begin{array}{l}\text { Unconsolidated sediments: } \\
\text { Basin-fill undifferentiated }\end{array}$ & Berger, 1995, p. 21 & $\begin{array}{l}\text { Desert Valley, } \\
\text { Nevada }\end{array}$ & Specific capacity & 19 & 110 & 180 & 5 to 320 \\
\hline $\begin{array}{l}\text { Unconsolidated sediments: } \\
\text { Basin-fill undifferentiated }\end{array}$ & Berger and others, 1997, p. 21 & $\begin{array}{l}\text { Spanish Springs } \\
\text { Valley, Nevada }\end{array}$ & Pumping test & several & $\mathrm{nr}$ & 330 & 0.5 to 12 \\
\hline $\begin{array}{l}\text { Unconsolidated sediments: } \\
\text { Basin-fill undifferentiated }\end{array}$ & Campana, 1987, p. 11 & $\begin{array}{l}\text { Dixie Valley, } \\
\text { Nevada }\end{array}$ & $\begin{array}{l}\text { Grain-size } \\
\text { analysis }\end{array}$ & 2 & $\mathrm{nr}$ & $\mathrm{nr}$ & 6 to 11 \\
\hline $\begin{array}{l}\text { Unconsolidated sediments: } \\
\text { Basin-fill undifferentiated }\end{array}$ & $\begin{array}{l}\text { CDM Engineers and Consultants, } \\
\text { Inc, 1997, table } 5\end{array}$ & $\begin{array}{l}\text { Warm Springs } \\
\text { Valley, Nevada }\end{array}$ & Pumping test & 9 & $\mathrm{nr}$ & 20 to 60 & 0.03 to 12 \\
\hline $\begin{array}{l}\text { Unconsolidated sediments: } \\
\text { Basin-fill undifferentiated }\end{array}$ & D.J. Donovan, unpub. data, 1996 & $\begin{array}{l}\text { Las Vegas Valley, } \\
\text { Nevada }\end{array}$ & Pumping test & 17 & $\mathrm{nr}$ & 100 to 250 & 5 to more than 80 \\
\hline $\begin{array}{l}\text { Unconsolidated sediments: } \\
\text { Basin-fill undifferentiated }\end{array}$ & $\begin{array}{l}\text { Earth Technology Corporation, } \\
\text { 1993, p. 3-2 }\end{array}$ & Fallon, Nevada & Slug test & 4 & $65-\mathrm{A}$ & 40 & 40 to 100 \\
\hline
\end{tabular}




\begin{tabular}{|c|c|c|c|c|c|c|c|}
\hline $\begin{array}{l}\text { Hydrogeologic } \\
\text { unit }\end{array}$ & Reference & Location & $\begin{array}{l}\text { Test type/ } \\
\text { data source }\end{array}$ & $\begin{array}{c}\text { Number } \\
\text { of } \\
\text { samples }\end{array}$ & $\begin{array}{c}\text { Mean } \\
\text { geometric - G } \\
\text { arithmetic - A } \\
\text { median - M } \\
\text { (ft/d) }\end{array}$ & $\begin{array}{l}\text { Thickness } \\
\text { tested } \\
\text { (ft) }\end{array}$ & $\begin{array}{l}\text { Range } \\
\text { (ft/d) }\end{array}$ \\
\hline $\begin{array}{l}\text { Unconsolidated sediments: } \\
\text { Basin-fill undifferentiated }\end{array}$ & Geomega, Inc., 1997, table 5-1 & $\begin{array}{l}\text { Northern White } \\
\text { River Valley, } \\
\text { Nevada }\end{array}$ & Pumping test & $\mathrm{nr}$ & $\mathrm{nr}$ & $\mathrm{nr}$ & $1 \times 10^{-3}$ to 400 \\
\hline $\begin{array}{l}\text { Unconsolidated sediments: } \\
\text { Basin-fill undifferentiated }\end{array}$ & $\begin{array}{l}\text { Groundwater Resources } \\
\text { Consultants, Inc., 1994, p. } 17\end{array}$ & $\begin{array}{l}\text { Warm Springs } \\
\text { Valley, Nevada }\end{array}$ & $\begin{array}{l}\text { Aquifer and slug } \\
\text { test }\end{array}$ & 27 & $0.33-\mathrm{G}$ & $\mathrm{nr}$ & 0.1 to 1 \\
\hline $\begin{array}{l}\text { Unconsolidated sediments: } \\
\text { Basin-fill undifferentiated }\end{array}$ & Handman and others, 1990, p. 15 & $\begin{array}{l}\text { Honey Lake Valley, } \\
\text { Nevada }\end{array}$ & Specific capacity & 36 & $8-\mathrm{M}$ & $\mathrm{nr}$ & $\mathrm{nr}$ \\
\hline $\begin{array}{l}\text { Unconsolidated sediments: } \\
\text { Basin-fill undifferentiated }\end{array}$ & Harrill and Prudic, 1998, p. A55 & Great Basin & Modeled values & $\mathrm{nr}$ & 4 to $20-\mathrm{G}$ & $\mathrm{nr}$ & 0.2 to 590 \\
\hline $\begin{array}{l}\text { Unconsolidated sediments: } \\
\text { Basin-fill undifferentiated }\end{array}$ & $\begin{array}{l}\text { Hydrologic Consultants, Inc., 2000, } \\
\text { table } 6\end{array}$ & Near Valmy, Nevada & Modeled values & $\mathrm{nr}$ & $\mathrm{nr}$ & $\mathrm{nr}$ & 0.1 to 5 \\
\hline $\begin{array}{l}\text { Unconsolidated sediments: } \\
\text { Basin-fill undifferentiated }\end{array}$ & JBR Consultants Group. 1989, p. 13 & $\begin{array}{l}\text { Near Winnemucca, } \\
\text { Nevada }\end{array}$ & Pumping test & 2 & $\mathrm{nr}$ & $\mathrm{nr}$ & $75-100$ \\
\hline $\begin{array}{l}\text { Unconsolidated sediments: } \\
\text { Basin-fill undifferentiated }\end{array}$ & $\begin{array}{l}\text { Knight Piesold and Co., 2002a, } \\
\text { appendix } 1\end{array}$ & Near Elko, Nevada & Pumping test & 1 & $\mathrm{~b}_{3}$ & 270 & $\mathrm{nr}$ \\
\hline $\begin{array}{l}\text { Unconsolidated sediments: } \\
\text { Basin-fill undifferentiated }\end{array}$ & Knight Piesold and Co., 2002b, p. 7 & Near Wells, Nevada & Pumping test & 1 & $\mathrm{~b}_{130}$ & $\mathrm{nr}$ & $\mathrm{nr}$ \\
\hline $\begin{array}{l}\text { Unconsolidated sediments: } \\
\text { Basin-fill undifferentiated }\end{array}$ & $\begin{array}{l}\text { Lander County and Nevada Rural } \\
\text { Water Association, } 2001\end{array}$ & $\begin{array}{l}\text { Near Austin, } \\
\text { Nevada }\end{array}$ & Pumping test & 1 & $\mathrm{~b}_{16}$ & 210 & $\mathrm{nr}$ \\
\hline $\begin{array}{l}\text { Unconsolidated sediments: } \\
\text { Basin-fill undifferentiated }\end{array}$ & $\begin{array}{l}\text { McDonald and Morrissey } \\
\text { Associates, Inc., 1998, table } 2\end{array}$ & Near Carlin, Nevada & $\begin{array}{l}\text { Pumping test and } \\
\text { specific capacity }\end{array}$ & 12 & $\mathrm{nr}$ & 100 to 500 & 2 to 100 \\
\hline $\begin{array}{l}\text { Unconsolidated sediments: } \\
\text { Basin-fill undifferentiated }\end{array}$ & Maurer and Welch, 2001, p. 25 & Near Fallon, Nevada & $\begin{array}{l}\text { Specific capacity/ } \\
\text { Pumping test }\end{array}$ & 11 & $\mathrm{nr}$ & $\mathrm{nr}$ & 3 to 60 \\
\hline $\begin{array}{l}\text { Unconsolidated sediments: } \\
\text { Basin-fill undifferentiated }\end{array}$ & Porter Geotechnical, 1997, p. 4 & $\begin{array}{l}\text { Near Sparks, } \\
\text { Nevada }\end{array}$ & $\begin{array}{l}\text { Slug test/ } \\
\text { Pumping test }\end{array}$ & 5 & $\mathrm{nr}$ & 23 & 15 to 160 \\
\hline $\begin{array}{l}\text { Unconsolidated sediments: } \\
\text { Basin-fill undifferentiated }\end{array}$ & $\begin{array}{l}\text { PTI Environmental Services, Inc., } \\
\text { 1994, table 6-6 }\end{array}$ & Near Ruth, Nevada & Pumping test & $\mathrm{nr}$ & $\mathrm{nr}$ & $\mathrm{nr}$ & 0.02 to 400 \\
\hline $\begin{array}{l}\text { Unconsolidated sediments: } \\
\text { Basin-fill undifferentiated }\end{array}$ & $\begin{array}{l}\text { PTI Environmental Services, Inc., } \\
\text { 1997, p. } 8\end{array}$ & $\begin{array}{l}\text { Near Fernley, } \\
\text { Nevada }\end{array}$ & Pumping test & 2 & $\mathrm{nr}$ & 542 & $20-70$ \\
\hline
\end{tabular}




\begin{tabular}{|c|c|c|c|c|c|c|c|}
\hline $\begin{array}{c}\text { Hydrogeologic } \\
\text { unit }\end{array}$ & Reference & Location & $\begin{array}{l}\text { Test type/ } \\
\text { data source }\end{array}$ & $\begin{array}{c}\text { Number } \\
\text { of } \\
\text { samples }\end{array}$ & $\begin{array}{c}\text { Mean } \\
\text { geometric - G } \\
\text { arithmetic - A } \\
\text { median - M } \\
\text { (ft/d) }\end{array}$ & $\begin{array}{c}\text { Thickness } \\
\text { tested } \\
\text { (ft) }\end{array}$ & $\begin{array}{c}\text { Range } \\
\text { (ft/d) }\end{array}$ \\
\hline $\begin{array}{l}\text { Unconsolidated sediments: } \\
\text { Basin-fill undifferentiated }\end{array}$ & $\begin{array}{l}\text { Star City and Nevada Rural Water } \\
\text { Association, 2002, p. } 12\end{array}$ & $\begin{array}{l}\text { Near Winnemucca, } \\
\text { Nevada }\end{array}$ & Pumping test & 1 & $\mathrm{~b}_{130}$ & 160 & $\mathrm{nr}$ \\
\hline $\begin{array}{l}\text { Unconsolidated sediments: } \\
\text { Basin-fill undifferentiated }\end{array}$ & $\begin{array}{l}\text { Wateresource Consulting Engineers, } \\
\text { Inc., 1993, appendix A }\end{array}$ & $\begin{array}{l}\text { Eagle Valley, } \\
\text { Nevada }\end{array}$ & Pumping test & 17 & $\mathrm{nr}$ & 100 to 700 & 2 to 50 \\
\hline $\begin{array}{l}\text { Unconsolidated sediments: } \\
\text { Alluvial fan, lower }\end{array}$ & $\begin{array}{l}\text { Belcher and others, 2001, } \\
\text { appendix A }\end{array}$ & Southern Nevada & Pumping test & 7 & $\mathrm{nr}$ & 20 to 370 & 7 to 180 \\
\hline $\begin{array}{l}\text { Unconsolidated sediments: } \\
\text { Alluvial fan, lower }\end{array}$ & Plume, 1996, p. B17 & Great Basin & Pumping test & 5 & $\begin{array}{l}63-\mathrm{A} \\
67-\mathrm{M}\end{array}$ & $\mathrm{nr}$ & 0.02 to 140 \\
\hline $\begin{array}{l}\text { Unconsolidated sediments: } \\
\text { Alluvial fan, lower }\end{array}$ & Handman and Kilroy, 1997, p. 48 & $\begin{array}{l}\text { Northern Big } \\
\text { Smoky Valley, } \\
\text { Nevada }\end{array}$ & Specific capacity & 26 & $\mathrm{nr}$ & $\mathrm{nr}$ & 8 to 14 \\
\hline $\begin{array}{l}\text { Unconsolidated sediments: } \\
\text { Alluvial fan, upper }\end{array}$ & $\begin{array}{l}\text { Belcher and others, 2001, } \\
\text { appendix A }\end{array}$ & Southern Nevada & Pumping test & 7 & $\mathrm{nr}$ & 100 to 230 & 0.5 to 80 \\
\hline $\begin{array}{l}\text { Unconsolidated sediments: } \\
\text { Alluvial fan, upper }\end{array}$ & Plume, 1996, p. B17 & Great Basin & Pumping test & 6 & $\begin{array}{l}103-\mathrm{A} \\
90-\mathrm{M}\end{array}$ & $\mathrm{nr}$ & 80 to 140 \\
\hline $\begin{array}{l}\text { Unconsolidated sediments: } \\
\text { Alluvial fan, upper }\end{array}$ & Handman and Kilroy, 1997, p. 48 & $\begin{array}{l}\text { Northern Big } \\
\text { Smoky Valley, } \\
\text { Nevada }\end{array}$ & Modeled values & $\mathrm{nr}$ & $\mathrm{nr}$ & $\mathrm{nr}$ & 14 to 100 \\
\hline $\begin{array}{l}\text { Unconsolidated sediments: } \\
\text { Alluvial fan, undifferentiated }\end{array}$ & $\begin{array}{l}\text { Belcher and others, 2001, } \\
\text { appendix A }\end{array}$ & Southern Nevada & Pumping test & 27 & $\mathrm{nr}$ & 20 to 530 & $2 \times 10^{-4}$ to 140 \\
\hline $\begin{array}{l}\text { Unconsolidated sediments: } \\
\text { Alluvial fan, undifferentiated }\end{array}$ & $\begin{array}{l}\text { Hydrologic Consultants, Inc., 2000, } \\
\text { table } 6\end{array}$ & Near Valmy, Nevada & Modeled value & $\mathrm{nr}$ & $\mathrm{b}_{5}$ & $\mathrm{nr}$ & $\mathrm{nr}$ \\
\hline $\begin{array}{l}\text { Unconsolidated sediments: } \\
\text { Alluvial fan, undifferentiated }\end{array}$ & Geomega, Inc., 1998a, p. 22 & $\begin{array}{l}\text { Near Beowawe, } \\
\text { Nevada }\end{array}$ & Pumping test & 3 & $\mathrm{nr}$ & 350 & 10 to 20 \\
\hline $\begin{array}{l}\text { Unconsolidated sediments: } \\
\text { Alluvial fan, undifferentiated }\end{array}$ & Geomega, Inc., 1998a, p. 22 & $\begin{array}{l}\text { Near Beowawe, } \\
\text { Nevada }\end{array}$ & Pumping test & several & $\mathrm{nr}$ & $\mathrm{nr}$ & 5 to 45 \\
\hline $\begin{array}{l}\text { Unconsolidated sediments: } \\
\text { Alluvial fan, undifferentiated }\end{array}$ & Harrill, 1986, p. 10 & $\begin{array}{l}\text { Near Pahrump, } \\
\text { Nevada }\end{array}$ & Literature search & $\mathrm{nr}$ & $\mathrm{nr}$ & $\mathrm{nr}$ & 0.1 to over 150 \\
\hline
\end{tabular}




\begin{tabular}{|c|c|c|c|c|c|c|c|}
\hline $\begin{array}{l}\text { Hydrogeologic } \\
\text { unit }\end{array}$ & Reference & Location & $\begin{array}{l}\text { Test type/ } \\
\text { data source }\end{array}$ & $\begin{array}{c}\text { Number } \\
\text { of } \\
\text { samples }\end{array}$ & $\begin{array}{c}\text { Mean } \\
\text { geometric - G } \\
\text { arithmetic - A } \\
\text { median - M } \\
(\mathrm{ft} / \mathrm{d})\end{array}$ & $\begin{array}{c}\text { Thickness } \\
\text { tested } \\
\text { (ft) }\end{array}$ & $\begin{array}{l}\text { Range } \\
\text { (ft/d) }\end{array}$ \\
\hline $\begin{array}{l}\text { Unconsolidated sediments: } \\
\text { Alluvial fan, undifferentiated }\end{array}$ & $\begin{array}{l}\text { Maurer, Berger, and Prudic, 1996, } \\
\text { p. } 21\end{array}$ & $\begin{array}{l}\text { Near Carson City, } \\
\text { Nevada }\end{array}$ & Slug test & 5 & $\mathrm{nr}$ & 20 & 4 to 20 \\
\hline $\begin{array}{l}\text { Unconsolidated sediments: } \\
\text { Alluvial fan, undifferentiated }\end{array}$ & Maurer and Berger, 1997, p. 11 & $\begin{array}{l}\text { Near Carson City, } \\
\text { Nevada }\end{array}$ & Slug test & 7 & $\mathrm{nr}$ & 22 to 36 & $9 \times 10^{-3}$ to 30 \\
\hline $\begin{array}{l}\text { Unconsolidated sediments: } \\
\text { Alluvial fan, undifferentiated }\end{array}$ & $\begin{array}{l}\text { Widmer and Van Hoozer, 1998, } \\
\text { p. } 16\end{array}$ & $\begin{array}{l}\text { South Truckee } \\
\text { Meadows }\end{array}$ & Pumping test & 12 & $\mathrm{nr}$ & $\mathrm{nr}$ & 1.5 to 13 \\
\hline $\begin{array}{l}\text { Unconsolidated sediments: } \\
\text { Valley floor }\end{array}$ & CH2MHill, 1986, p. 16 & $\begin{array}{l}\text { Southern Truckee } \\
\text { Meadows, Nevada }\end{array}$ & Pumping test & 2 & $\mathrm{nr}$ & $\mathrm{nr}$ & 5 to 17 \\
\hline $\begin{array}{l}\text { Unconsolidated sediments: } \\
\text { Valley floor }\end{array}$ & Handman and Kilroy, 1997, p. 48 & $\begin{array}{l}\text { Northern Big } \\
\text { Smoky Valley, } \\
\text { Nevada }\end{array}$ & Modeled values & $\mathrm{nr}$ & $\mathrm{nr}$ & $\mathrm{nr}$ & 2 to 8 \\
\hline $\begin{array}{l}\text { Unconsolidated sediments: } \\
\text { Valley floor }\end{array}$ & Maurer, 1986, p. 29 & $\begin{array}{l}\text { Carson Valley, } \\
\text { Nevada }\end{array}$ & Specific capacity & 150 & $\mathrm{nr}$ & $\mathrm{nr}$ & 9 to 90 \\
\hline $\begin{array}{l}\text { Unconsolidated sediments: } \\
\text { Valley floor }\end{array}$ & Maurer and Welch, 2001, p. 25 & Near Fallon, Nevada & $\begin{array}{l}\text { Specific capacity/ } \\
\text { Pumping test }\end{array}$ & 11 & $\mathrm{nr}$ & $\mathrm{nr}$ & 3 to 60 \\
\hline $\begin{array}{l}\text { Unconsolidated sediments: } \\
\text { Playa }\end{array}$ & Bedinger and others, 1986 , table 1 & Basin and Range & Literature search & $\mathrm{nr}$ & $7 \times 10^{-4}-\mathrm{G}$ & $\mathrm{nr}$ & a $3 \times 10^{-5}$ to $7 \times 10^{-3}$ \\
\hline $\begin{array}{l}\text { Unconsolidated sediments: } \\
\text { Playa }\end{array}$ & Belcher and others, 2001, table 2 & Southern Nevada & Pumping test & 13 & $\begin{array}{l}10-\mathrm{G} \\
36-\mathrm{A}\end{array}$ & 1 to 770 & ${ }^{\mathrm{c}} 0.01$ to 100 \\
\hline $\begin{array}{l}\text { Unconsolidated sediments: } \\
\text { Playa }\end{array}$ & Handman and Kilroy, 1997, p. 48 & $\begin{array}{l}\text { Northern Big } \\
\text { Smoky Valley, } \\
\text { Nevada }\end{array}$ & Modeled values & $\mathrm{nr}$ & $\mathrm{nr}$ & $\mathrm{nr}$ & less than 2 \\
\hline $\begin{array}{l}\text { Unconsolidated sediments: } \\
\text { Playa }\end{array}$ & Harrill, 1986, p. 10 & $\begin{array}{l}\text { Near Pahrump, } \\
\text { Nevada }\end{array}$ & Literature search & $\mathrm{nr}$ & $\mathrm{nr}$ & $\mathrm{nr}$ & $1 \times 10^{-3}$ to 1.6 \\
\hline $\begin{array}{l}\text { Unconsolidated sediments: } \\
\text { Playa }\end{array}$ & $\begin{array}{l}\text { Hydrologic Consultants, Inc., 2000, } \\
\text { table } 6\end{array}$ & Near Valmy, Nevada & Modeled values & $\mathrm{nr}$ & ${ }^{b} 0.1$ & $\mathrm{nr}$ & $\mathrm{nr}$ \\
\hline
\end{tabular}

${ }^{\mathrm{a}}$ Range is for 16.5 and 83.5 percentiles.

${ }^{\mathrm{b}}$ Mean is single reported value.

${ }^{\mathrm{c}} \mathrm{High}$ range value may not represent clayey playa deposits. 